University of Nebraska - Lincoln

DigitalCommons@University of Nebraska - Lincoln

2011

Ship to Shore: Inuit, Early Europeans, and Maritime Landscapes in the Northern Gulf of St. Lawrence

William W. Fitzhugh

Anja Herzog

Sophia Perdikaris

Brenna McLeod

Follow this and additional works at: https://digitalcommons.unl.edu/global

Part of the Archaeological Anthropology Commons, International and Area Studies Commons, and the Nature and Society Relations Commons

This Article is brought to you for free and open access by the School of Global Integrative Studies at DigitalCommons@University of Nebraska - Lincoln. It has been accepted for inclusion in Global Studies Papers \& Publications by an authorized administrator of DigitalCommons@University of Nebraska - Lincoln. 


\title{
Ship to Shore: Inuit, Early Europeans, and Maritime Landscapes in the Northern Gulf of St. Lawrence
}

\author{
William W. Fitzhugh, ${ }^{1}$ Anja Herzog, ${ }^{2}$ Sophia Perdikaris, ${ }^{3}$ \\ and Brenna McLeod ${ }^{4}$
}

1. Department of Anthropology, Smithsonian Institution, Washington, DC, USA

2. CELAT/Department of History, Laval University, Québec City, Québec, Canada

3. Department of Anthropology, City College of New York, New York City, New York, USA

4. Natural Resource DNA Profiling and Forensic Centre, Trent University, Peterborough, Ontario, Canada

Corresponding author - W. W. Fitzhugh, Department of Anthropology, Smithsonian Institution, PO Box 37012, Washington, DC 20013, USA. email fitzhugh@si.edu

Recent research at Hare Harbor on the Quebec Lower North Shore (LNS) in the northeastern Gulf of St. Lawrence reveals great potential for archaeological and historical research on Basque and other early European activities in the northwestern North Atlantic. Although considerable data have been retrieved from Red Bay, Labrador, and a few other sixteenthcentury sites in the Strait of Belle Isle and Gulf of St. Lawrence (Niellon 1986; Drouin 1988; Tuck and Grenier 1989; Grenier et al. 2007; Proulx 2007), archaeological knowledge of the early European phase of North American history in this region is limited, and information about post-sixteenth-century Basque occupations is nearly nonexistent. This chapter reports on a multicomponent site with late sixteenth-century Basque and late seventeenth/ early eighteenth-century European (possibly Basque) and Inuit occupations at Hare Harbor, Petit Mécatina Island, $200 \mathrm{~km}$ west of the Strait of Belle Isle. The later historic occupation includes hearths, middens, and ballast piles from adjacent land and underwater sites. In addition to domestic cooking hearths and ballast piles associated with the sixteenth-century Basque occupation, the site's later component contains two structures with paved stone 
floors, one interpreted as a cookhouse and the other as a blacksmith shop. The ethnic/national origin of these structures, which in earlier reports was designated as Basque on the basis of coarse earthenwares and large amounts of roof tiles, is now equivocal. Excavations in 2009 revealed a sixteenth-century Basque component adjacent to and deeper than the cookhouse (Structure 1) paved floor, raising the possibility that the cookhouse and blacksmith deposits may have a north Biscayan or Channel origin. Excavation also revealed a Labrador Inuit settlement that may be contemporary with the later European occupation. Information recovered from the European and Inuit contexts documents changing economic, social, and political conditions, including the appearance of Inuit in the Gulf of St. Lawrence and their participation in a European cod fishery at Hare Harbor. Given the breadth of activity, changes in technology and economy, and complex international and ethnic relations, a maritime landscape approach that links shore deposits with those from the underwater site over a period of more than 100 years provides a useful framework for interpreting the many strands of evidence from this small but fascinating site situated at the interface of European and Native nations, cultures, and traditions.

Utilization of the landscape concept for interpreting maritime anthropology and archaeological sites is relatively novel. Landscape archaeology has traditionally been applied at terrestrial sites to link archaeological components with their broader ecological and social settings, including subsistence resource zones, site hierarchies, settlement patterns, and regional economic networks. Recently, this concept has been extended to maritime anthropological studies in circumpolar and subantarctic settings (Westerdahl 2010), but it has rarely been a component of underwater archaeological inquiry. The fortuitous adjacency of both land and marine components at a Basque/European/Inuit site makes Hare Harbor an ideal case study for exploring the utility of the landscape approach in a maritime archaeology context.

\section{Background I: Basque Whaling}

Following the discovery of sixteenth-century Basque whaling stations at Red Bay and other locations in southern Labrador in the mid-1970s, Basque sites were quickly identified throughout much of the Grand Bay region, the Basque name for the Gulf of St. Lawrence (Fig. 6.1). The revelation began with records from 1530 to 1580 discovered by Selma Huxley Barkham in the Spanish Basque archives showing large numbers of Basque vessels sailed annually to harbors in the Strait and Gulf of St. Lawrence. The frequency of Spanish and French Basque voyages varied widely throughout the sixteenth century and reached their peak in the 1570s when Spanish Basques sent as many as 20-30 vessels yearly to Grand Bay (Loewen 2009:9). Unlike most other early European venturers who were primarily fishermen and traders, Basque whalers lived aboard their vessels and used shore bases mainly for butchering whales, rendering blubber, casking oil, smithing, and other industrial activities, which they conducted under open-sided, tiled-roofed shelters (Proulx 1993, 2007). Ships sailed from homeports along the Biscayan coasts of France and northern Spain in early summer ballasted with cargoes of clay tiles, prefabricated barrels, disassembled chalupas (whaleboats), and whaling gear. Reaching Newfoundland and Labrador Grand Bay harbors in June just as the sea ice melted, they pursued whales throughout the summer 
and returned to Europe with oil, fish, wood, and other products when their harbors began to freeze over in late fall (Loewen 2009). A good season produced as many as 1,000 barrels of oil per vessel. However, many vessels were lost at sea or were wrecked or trapped by ice in their harbors after snap frosts forced crews to overwinter with great hardship and loss of life. The ensuing legal proceedings produced records that led to the archaeological discoveries.

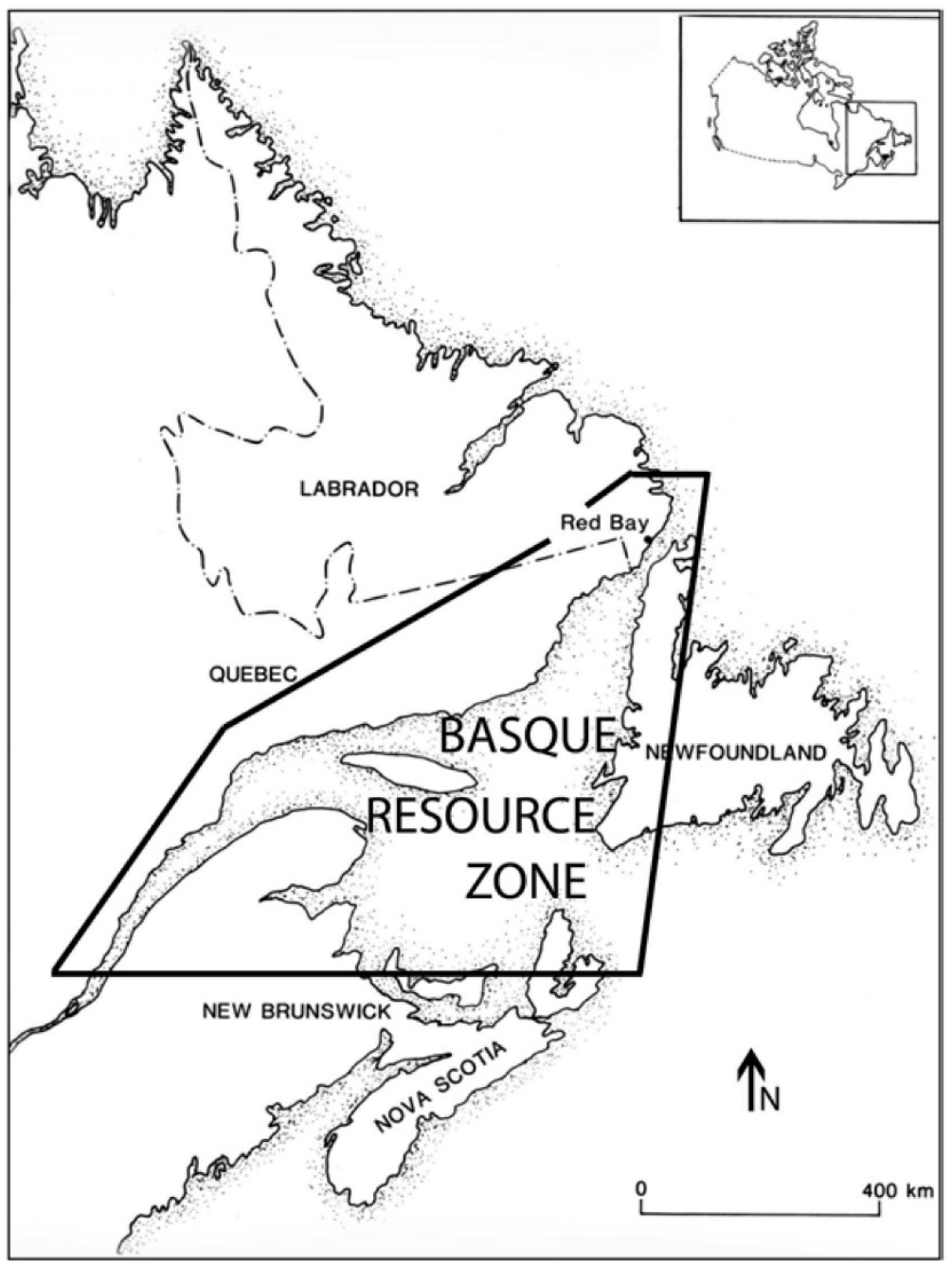

Figure 6.1. Map of Basque resource zone in the Gulf of St. Lawrence (figure by W. Fitzhugh, 2009).

Historical work by Selma and Michael Barkham and others (Barkham 1980, 1984; Huxley 1987; Barkham 1994; Turgeon 1994, 1995; Loewen 2009) and archaeological excavations conducted at Red Bay (Tuck 1982, 1983-1986; Tuck and Grenier 1989; Grenier 1988; Grenier et al. 2007) and other Basque sites in the Gulf (Niellon and Jones 1984; Niellon 1986; Niellon 
and McGain 1987; Lalande 1989; Auger et al. 1992; Azkarate et al. 1992) provide documentation of this early chapter of New World maritime history; however, many aspects are still unclear: How did Basque shipbuilding and whaling develop in the Bay of Biscay in the centuries before 1500 ? Why is there so little historical note or archaeological evidence of Basque contact with Native American Indians and Inuit? Was Basque whaling responsible for the decline of the North Atlantic right whale population (Rastogi et al. 2004)? And what was the Basque maritime role in Newfoundland waters after the Basque decline following the 1580 s?

To date, most attention to early New World Basque history and archaeology has been devoted to the sixteenth century heyday of Basque whaling from 1530 to 1580 . After this, following commercial and shipping losses to the Dutch and English, reassignment of vessels to the India trade, and the 1588 Armada catastrophe, the Spanish Basque largely abandoned the American fishery. However, in the latter part of the seventeenth century, Spanish and French Basque vessels returned sporadically and in small numbers to fish and trade in the Gulf (Trudel 1978, 1980; Barkham 1994; Turgeon 1994; Loewen 2009). To date, there has been no archaeological evidence of post-1600 Basque voyages or information about how these enterprises were conducted; how Basques adapted to changing ecological conditions following the depletion of whale stocks; how their operations dealt with the new economies and politics of seventeenth-century Europe; and how field operations were affected by Dutch, French, English, American, and Native competitors. It seemed that Hare Harbor offered an opportunity to explore these questions with archaeological data. The only other comparable site is a ca. 1610-1650 whaling station at Strákatangi, Steingrímsfjörđur, northwestern Iceland, which has been described as having a Basque component (Edvardsson and Rafnsson 2006). The problem in such identification is the difficulty, without historical documentation, determining what a seventeenth/eighteenth-century Basque archaeological complex should look like, given the absence so far of homeland sites of this period and precise historical documentation. We return to this problem later in this chapter.

One of the most surprising aspects of the New World Basque historical narrative for the Grand Bay region is the paucity of documentation about interactions with the diverse Native landscape, which included Miq'maw, Iroquois, Innu, Beothuk, Inuit, and others. The relative lack of Inuit contact with Basques noted by Barkham (1980) has been attributed to hostilities, Native avoidance, absence of year-round Basque habitation, and lack of Native participation in whaling operations. However, it stands to reason that the history of relations documented in the Strait of Belle Isle may not hold for the entire Grand Bay region. The fact that pidgin dialects developed between Basques, Miq'maw, and Innu in Nova Scotia, southern Newfoundland, and the northern Gulf (Bakker 1989) suggests that interactions with Basques were more extensive than presently understood. Through Hare Harbor, we may begin to explore the ecological, social, ethnic, political, and economic dimensions of an early maritime landscape that Cleophas Belvin (2006) calls the "forgotten" Labrador. 


\section{Background II: The French Cod Fisheries}

European cod-fishing activities in the New World have been documented back to the very beginning of the sixteenth century, and despite great variability over time, this migratory fishery lasted for several centuries. The fishing fleets, comprising at least in the sixteenth century literally hundreds of fishing vessels from many French, Spanish, Portuguese, and English ports, made "green" (undried) cod on the Grand Banks off the southeastern coast of Newfoundland or dried cod in numerous harbors along the coasts of Newfoundland, Acadia, Cape Breton, southern Labrador, and further into the Gulf of St. Lawrence at Baie des Chaleurs and on the Gaspé peninsula.

In the course of the seventeenth and eighteenth centuries, the cod fishery had to adapt to numerous constraints, and consequently patterns of occupation along the coasts varied over time. While fierce competition among the fishermen contributed to much variability in fishing locations, the establishment of sedentary fisheries within the range of the French and English colonial efforts gave rise to additional conflicts over fishing rooms in Newfoundland, Acadia, and Gaspé, despite some existing legislation protecting the rights of the migratory fishery. In addition, piracy and illegal trade accentuated difficulties in Acadia and Newfoundland. Conflicts with Inuit incursions also hampered activities in southern Labrador and northern Newfoundland, and changes in the availability of fish related to changes in climate and currents also caused bad fishing seasons in various localities. By the end of the seventeenth century, European conflict added to these difficulties as the War of the Grand Alliance (League of Augsburg, 1688-1697) and soon thereafter the War of Spanish Succession (1701-1714) lead to successive shifts in political control over Acadia, profoundly affecting local population as well as the migratory fisheries, bringing instability, war fleets, conquest, illegal trade, and piracy into the region. In addition, during these conflicts most French fishermen were banned by France from fishing in Newfoundland's Petit North. This period of difficulties was resolved by the Treaty of Utrecht in 1713, which left Newfoundland and Acadia under permanent English control.

Such a variety of problems may well have given rise, during the turn of the eighteenth century, to the search for new and more advantageous fishing grounds; a search, that may well have brought French cod-fishing vessels, whether sailing from Brittany, Normandy, or the Basque ports, to the then little-exploited LNS of the Gulf of St. Lawrence. While Portuguese fishermen had been banned from Newfoundland by the English in the course of the seventeenth century, Breton fishermen had preferably gone fishing for cod along the Petit Nord, the south coast of Newfoundland, St. Pierre and Miquelon islands, as well as in southern Labrador; Norman ships had gone to the east coast of the island and to St. Pierre and Miquelon; and French Basque vessels had mainly steered to southwestern Newfoundland harbors such as Placentia, where the Spanish Basque had also maintained fishing rights during the seventeenth century, as well as to Cape Breton, Acadia, and Île Percée in Gaspé (de la Morandière 1962; Pope 2004). The LNS, however, as data from Petit Mécatina Island now seem to indicate, also saw the onset of increased commercial fishing for cod in the late seventeenth century. Offering a particularly well-protected and hidden harbor in the heart of the Gulf of St. Lawrence, this outer coast island with close access to fishing and whaling grounds became a center for several migratory commercial ventures 
and "close encounters" in a marginal setting between the sixteenth and the eighteenth centuries.

By the late 1730s, this part of the LNS would see the establishment of French colonial sealing and trading posts along its coast, and after the English conquest of 1759 and particularly in the nineteenth century, it would also be open to exploitation by egg-hunters from Nova Scotia as well as by American fishermen and whalers.

\section{Site Description and Excavations}

In 2001, while surveying the Quebec LNS, the Smithsonian's St. Lawrence Gateways Project discovered sites at Hare Harbor on Petit Mécatina Island and Boulet Harbor near Mutton Bay that contained large amounts of clay roof tiles (Fitzhugh 2006:58, 61-74). The tiles suggested these sites were typical sixteenth-century Basque whaling stations such as Red Bay. However, when excavations began to yield clay pipes, stoneware, and glass beads, site dating became more complicated, as these materials had not previously been found in Basque whaling contexts. The sites also were unusual in lacking try-works and were located in remote locations full of shoals and navigation hazards rather than at easily accessible harbors on open coasts. Such conditions helped make this portion of the Quebec LNS a haven for smugglers and pirates, and it remained a zone of confrontation between rival European powers until the nineteenth century (Belvin 2006:85).

Hare Harbor is a small, narrow bay near the southeastern tip of Petit Mécatina Island $10 \mathrm{~km}$ east of the modern English-speaking fishing village of Harrington Harbor. Its outer coast setting provides quick access to fishing and hunting grounds, where cod (Gadus morhua), harp seal (Pagophilis groenlandicus), and numerous whale species are seasonally available. A narrow entrance hides the harbor and its site area from passing vessels, but once inside the entrance the harbor is deep and open, revealing a conspicuous $150 \mathrm{~m}$ high cliff with a $100 \mathrm{~m}$ long south-facing dry shelter at its base. This cliff and shelter form the northern border of the site, which lies in a grassy meadow south of the cliff bounded to the south by a rocky ridge. Sea cliffs and a deep cove provide a protected anchorage and shore access at the western edge of the site, and a freshwater stream enters at the head of the harbor.

Hare Harbor-1 (EdBt-3, Fig. 6.2) lies on a postglacial marine beach about $8,000 \mathrm{~m}^{2}$ in extent. Above a steep shore-side bank, grass- and alder-covered ground slopes gently up to a beach crest, where the land flattens out and the soil becomes boggy and gives way to spruce, alder thickets, and bog. A few hundred meters farther east, beside a small pond, there is a small nineteenth-century stone house foundation and midden designated Hare Harbor-2 (EdBt-6). No trace of this material has been found at Hare Harbor-1, although scattered post- 1750 artifacts occur on the sediment surface of the adjacent Hare Harbor-1 underwater site. 


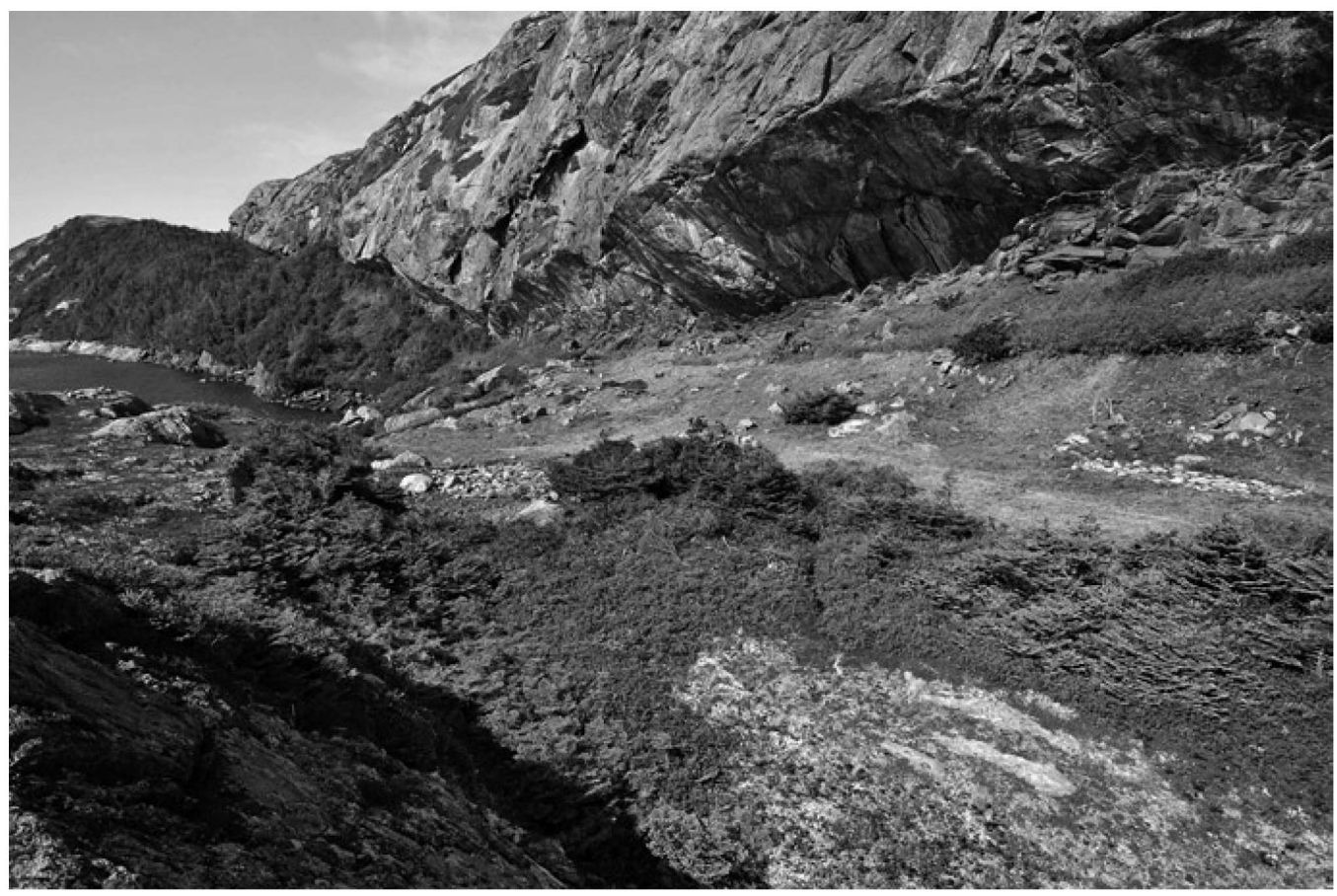

Figure 6.2. Hare Harbor-1 site environs (photo by W. Richard, 2008).

The initial tests at the Hare Harbor- 1 land site produced roof tiles, iron spikes, ceramics, and charcoal throughout the site area in a 5-10 cm thick cultural level resting on sterile beach sand. Excavations from 2002 to 2009 (Fig. 6.3) revealed structures interpreted as a cookhouse and a smithy or cooperage, stratified middens, and activity areas, while underwater excavations in the anchorage to the west revealed ballast piles and stratified middens containing wood debitage, whale bones, and fish remains. Native American finds are so far limited to the land site and include a ca. $600 \mathrm{BC}$ (uncalibrated radiocarbon years) Groswater Paleoeskimo hearth, a ca. AD 1700 Inuit winter house below the Basque smithy, and two as yet unexcavated Inuit winter houses at the northwest end of the site area. Popular accounts (Malakoff 2007; Gupta 2009), numerous field reports (Fitzhugh 2001-2010, 2006-2010), and published papers (Fitzhugh 2006; Fitzhugh et al. 2008) describe research to date. 


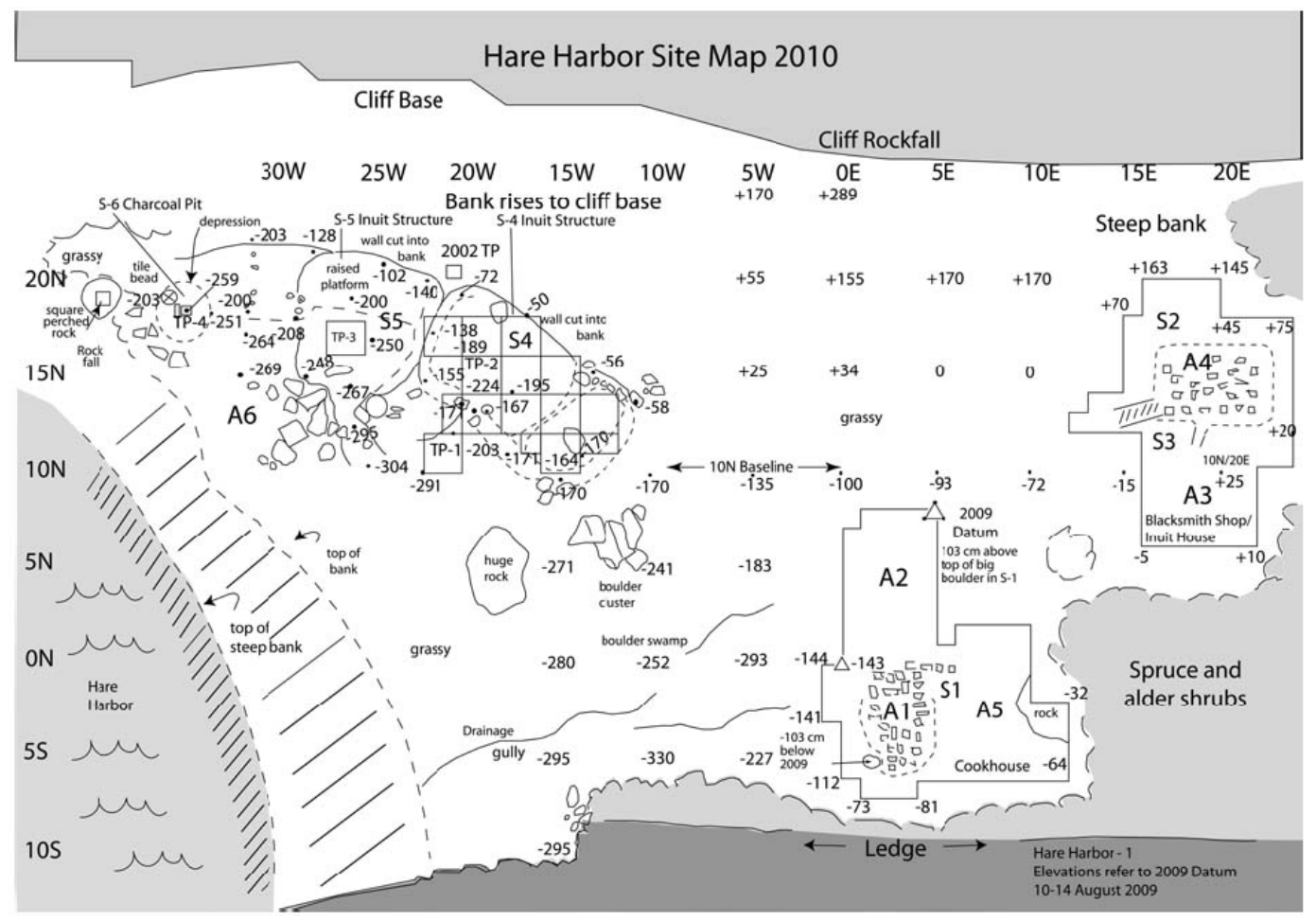

Figure 6.3. Harbor Harbor-1 site map (figure by H. Kim and L. Marr, 2009).

\section{Structure 1 (Cookhouse)}

Structure 1 (S-1) is a rectangular, $12 \times 14 \mathrm{~m}$ stone pavement that had large amounts of frostshattered roof tile in a black earth $5-15 \mathrm{~cm}$ thick cultural layer above the floor. This layer appeared to be a single undifferentiated deposit containing tiles, charcoal, and artifacts. Large, relatively intact tiles were found throughout the pavement area but were heaviest around its outer portions and beyond its margins, where they occurred in highly fragmented condition. It appeared that these shattered tiles were the detritus of numerous retiling episodes. The structure had a large, roughly built, stone-walled hearth pit in the southern part of the pavement. This hearth was poorly integrated into the pavement architecture and probably dates to a later period. Finds from the floor deposit include domestic utility Iberian and southwestern French earthenware, Normandy stoneware (found primarily in the large pit hearth), a variety of glass bottles and fine glassware, iron spikes and nails, charcoal, cork, flint, clay pipe fragments, and glass beads (Herzog 2008). Neutron activation analysis of the beads found throughout the pavement indicates a dating range of 1680-1730 (Herzog and Moreau 2004, 2006). Fragments of Inuit soapstone cooking pots and oil lamps were also found on and among the pavement stones in the western portion of the floor, which also was marked in two areas with charred blubber encrustations similar to oil lamp stains in Inuit winter houses. These finds and the domestic nature of the European material suggest this structure served as a cookhouse or all-purpose 
domestic center. Soapstone lamp and vessel fragments indicate the presence of one or more female Inuit occupants.

Finds on beach deposits north of Structure 1 produced tiles, ceramics, glass beads, iron spikes, and a beaked lamp of iron identical to one found at Red Bay (Tuck and Grenier 1989:50). A few meters to the east, a water-saturated bog yielded tiles, nails, ceramics, an iron maul, and wooden artifacts including barrel parts, a garment or bag pin, a wheelturned bowl, and quantities of axe-cut brush. Stratigraphy at the southern edge of the bog shows alternating layers of charcoal-stained peat and clean trampled peat that document occupation episodes separated by lapses long enough for revegetation.

\section{Structure 2 (Smithy/Cooper's Shop)}

Structure 2 is defined by a $6 \times 8$-m stone pavement whose cultural layer included charcoal underlain by black earth containing fewer tiles and a more industrial deposit than S-1, including iron bar stock, a broken anchor, flintlock gun parts, French and English gun flints, iron spikes, a wood-handled awl, a ship's lead-line weight, and only a few glass beads, and clay pipe fragments. This structure appears to have been a smithy or cooper's shop. Extending from the western side of the structure we found part of a $1.5 \mathrm{~m}$ wide pathway of crushed roof tiles leading across the boggy soil toward S-1.

\section{Structure 3 (The Eastern Inuit Winter House)}

Immediately beneath the Structure 2 pavement, without separation by intervening deposits, we found a $4 \times 8$-m rectangular wood-paved floor, designated Structure 3 (Fig. 6.4), enclosed by $\log$ foundation footings. The upper surfaces of these footings were heavily charred, as were the upper sides of the barrel staves, tub bottoms, and wood planks that composed the interior floor of this earlier structure. Calcined bone ash occurred in many areas inside the house along with charred remnants of canvas-like fabric, and a few glass beads, nails, and fragments of tile and earthenware. Upon this floor, we found an Inuit lamp-wick trimmer, two miniature toy Inuit soapstone lamps, and fragments of two toy hunting bows, also of Inuit construction. Extending south from this floor, below three large slabs that had framed a doorway, a 5-m long tunnel-like entrance passage had been excavated $40-50 \mathrm{~cm}$ into the peat, $30-50 \mathrm{~cm}$ below the level of the house floor. The passage exited into the bog to the south and was paved with clay tiles and rock slabs, with a thick upright slab serving as a cold trap where the passageway entered the house. A small, rectangular wooden European-style toolbox with a carrying handle had been turned upside down to serve as a step into the house. Two roof tiles were set into the passage floor next to the box, and part of a lathe-turned wood platter was wedged between the box and the tunnel wall. Entrance passages of this type are diagnostic of historic period Labrador Inuit winter houses. The charred floors, sills, and artifacts indicate that the entire house had been consumed in a fire that not only charred the floor boards but also turned all bone material (food bone or possibly human remains, see below) into calcined paste. The family living here included children and utilized a mixture of Inuit and European technology and materials. Following the conflagration, before vegetation or other deposits accumulated, the charred floor was covered with heavy rock slabs that formed the floor of a smithy or cooper's shop. 


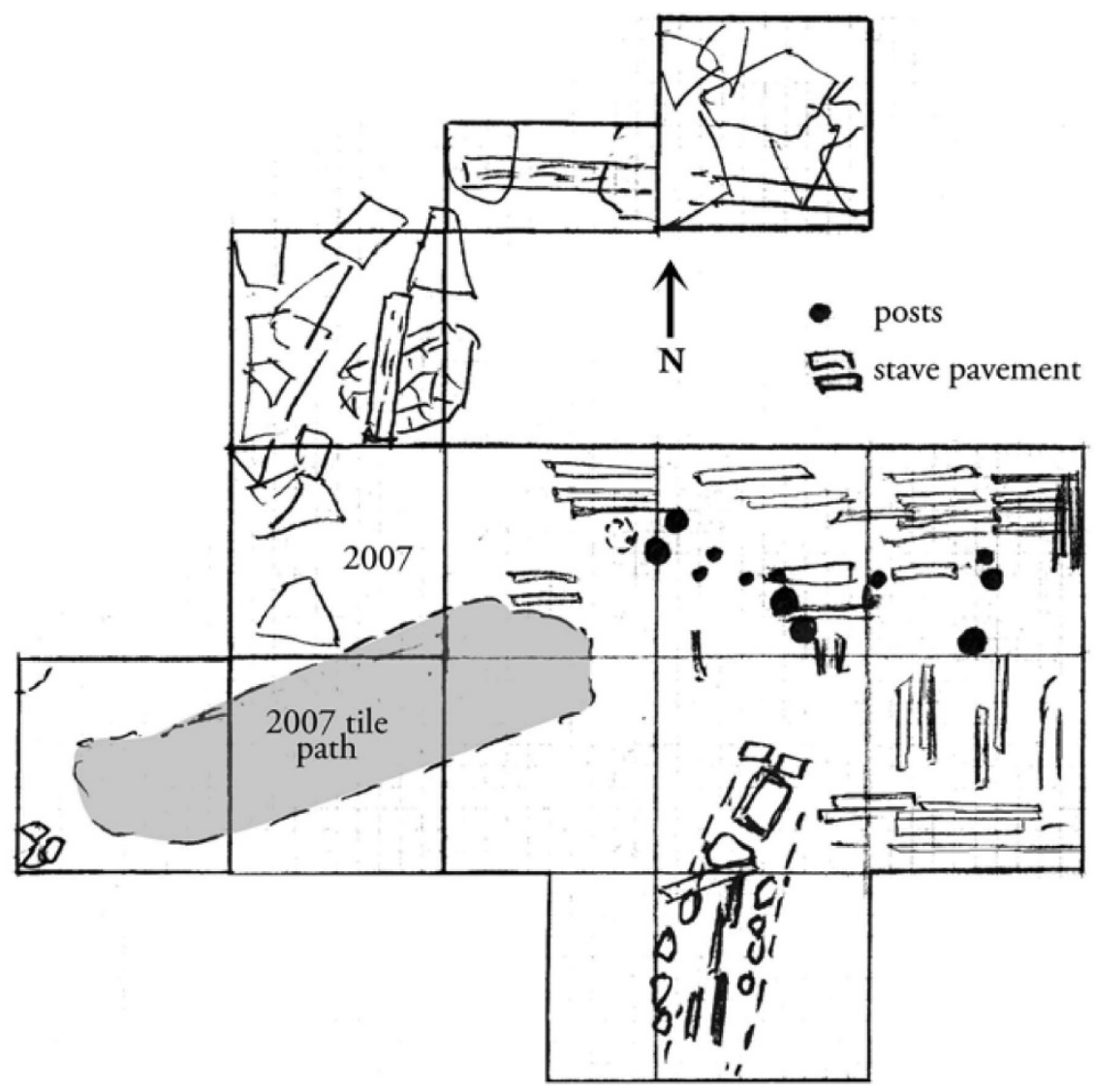

Figure 6.4. Structure 3, the burned floor of an Inuit winter house (figure by W. Fitzhugh, 2009).

\section{Structures 4 and 5 (The Northwestern Inuit Houses and Charcoal Pit)}

In 2009, a large rectangular Inuit-style winter dwelling (Structure 4), a smaller structure (Structure 5, possibly Inuit), and a charcoal-filled pit were discovered in the northwest corner of the site. Structure 4 is a rectangular $6 \times 8 \mathrm{~m}$ dwelling with a paved interior and a $4 \mathrm{~m}$ long entrance passage. Test pits produced large amounts of charcoal and European ceramics (sometimes nearly whole vessels of stoneware and earthenware); roof tiles; bottle glass; clay pipe fragments; an iron axe (like one found in the S-1 upper tile midden); objects of lead including musket balls, two cod jiggers, and a lead knife handle; and a large corroded mass of iron nails. The presence of a bag of nails, an axe, large ceramic fragments, and loose charcoal on the house floor suggested conflagration and rapid abandonment. Structure 5, rectangular and approximately $4 \times 5 \mathrm{~m}$, also has a south-side entrance passage. A test pit in its cobble-paved floor produced roof tiles, nails, tan earthenware, and a piece of goblet glass. A depression nearby yielded a large quantity of charcoal, suggesting this feature may have been used to prepare charcoal, perhaps for the smithy. The fact that Structures 3 and 4 are of Inuit construction and contain European artifacts identical to those found in Structures 1 and 2 and that S-1 contained numerous pieces of Inuit 
soapstone lamps and cooking vessels suggests that these structures are contemporaneous and that one or more Inuit families were living at the site during the later European codfishing operation.

\section{The Underwater Site}

Three seasons of underwater surveys and excavations in the adjacent cove revealed extensive Basque remains on a steeply sloping bottom extending from shore to a depth of $20 \mathrm{~m}$, covering a 2,000 $\mathrm{m}^{2}$ area (Fig. 6.5). In addition to abundant clay tiles and finds of ceramic vessels identical with those on land, the underwater site has 11 ballast piles composed of limestone and other rocks. These piles were formed by repeated de-ballasting. A series of test pits excavated from shore to $16 \mathrm{~m}$ depth revealed a 1-m-thick midden with a consistent stratigraphic profile consisting of a basal level of peat mixed with tiles overlain by a layer of axe-cut wood, a third level containing whalebones, a fourth layer of concentrated codfish bones with some minor elements of other fish, seal, and bird remains, and a fifth upper level of sandy silt, ballast rock, and tile (Phaneuf 2008). Similar types of deposits were found in the shore-trench at the Red Bay underwater site (Stevens and Cumbaa 2007:I:195; Phaneuf 2008:83).

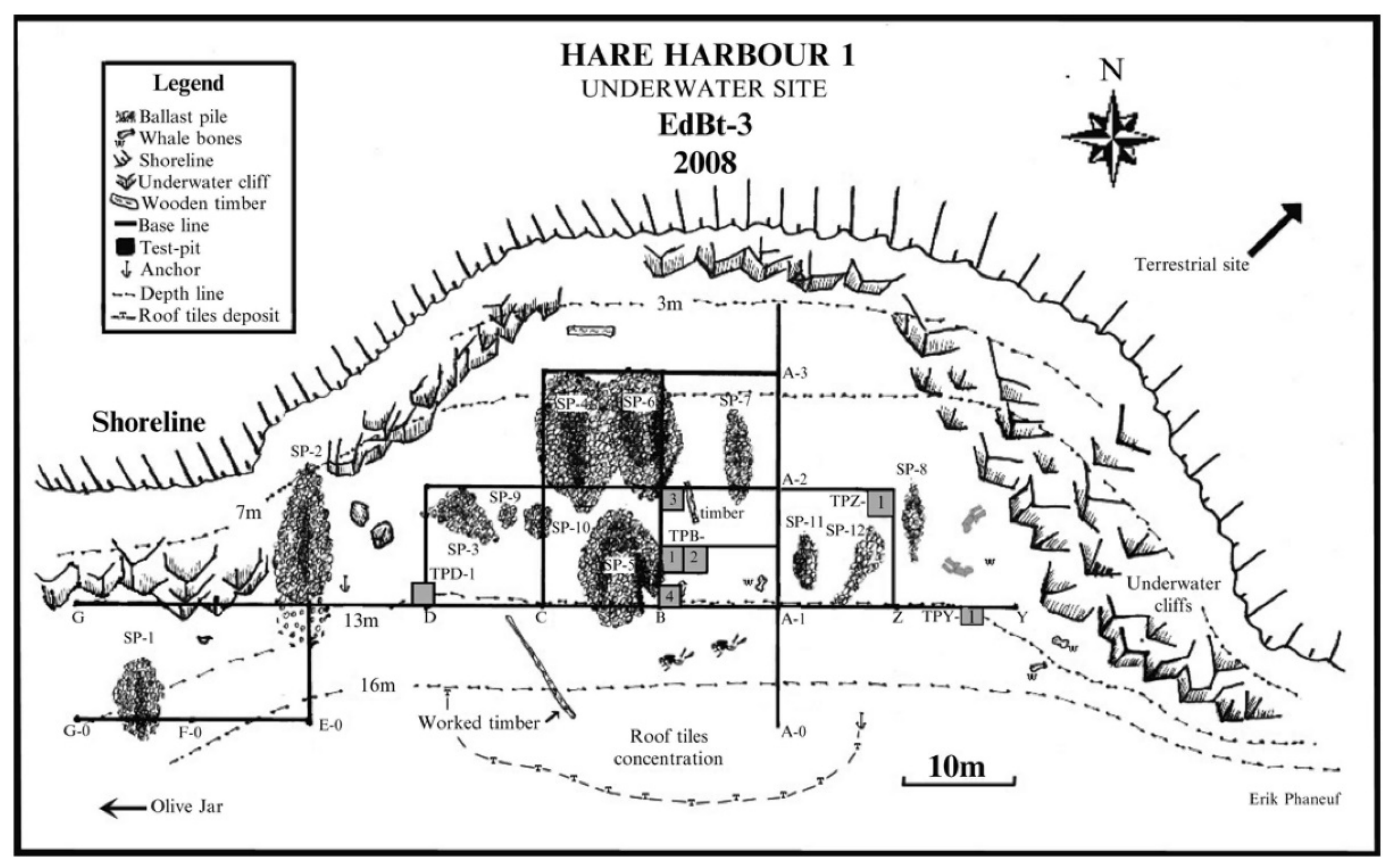

Figure 6.5. Hare Harbor-1 underwater site plan showing ballast piles and excavation areas (map by E. Phaneuf, F. Simard, and B. Ford, 2008).

\section{The Ceramic Collection}

The ceramic collection from Hare Harbor-1 is extremely varied (Herzog 2008, 2009, 2010). Of the 656 sherds collected during land and underwater excavations from 2001 to 2007 
associated with the pre-nineteenth century occupation of Hare Harbor, more than $60 \%$ (417 sherds) are glazed and unglazed earthenwares, which can be divided into 25 different types. In addition, 153 sherds belong to stoneware vessels of two different types, and 86 sherds are of tin-glazed earthenware (Table 6.1). Many of the finds are described and illustrated in more detail elsewhere (Herzog 2008). The collection was analyzed to help establish a date for the occupational history of the site and to determine the origin of those who came to Hare Harbor during its use as a whaling and cod-fishing station. As might be expected, the variability of the collection indicates a complex history. Although this analysis does not include artifacts recovered during the 2008 underwater and Structure 3 Inuit house excavations, or the 2009 Structure 1 lower level (sixteenth century), and Structures 4, 5 (seventeenth/eighteenth-century Inuit house) excavations, a summary of visual examination of these collections has shown a general correspondence between these collections, and no new ceramic types are to be added to the collection for the time being.

\begin{tabular}{lcccc}
\hline \multicolumn{1}{l}{ Table 6.1. The Hare Harbor-1 ceramic collection } & & \\
\hline Type & \# Sherds & \# Vessels & \% Sherds & \% Vessels \\
\hline Earthenware & 417 & 83 & 63.6 & 74.1 \\
Stoneware & 153 & 7 & 23.3 & 6.3 \\
Majolica & 86 & 22 & 13.1 & 19.6 \\
Total & 656 & 112 & 100.0 & 100.0 \\
\hline
\end{tabular}

Analysis of the ceramic collection has shown that some of the material compares well to ceramics known from other Basque sites, which are usually dated to the late sixteenth and early seventeenth centuries. The most important type among these is the earthenware cooking vessel (marmite) carrying applied bands decorated with roulette impressions on its body (Fig. 6.6a; cf. Grenier et al. 2007: Fig. 9.1.6 and 7 in Gusset 2007:II:64). Such vessels have become the hallmark of finds on Basque whaling stations, and as many as 18 individual vessels of this type may be represented in the Hare Harbor collection. Their provenance still remains unknown, which makes assigning a date for production and use difficult; but they were probably made in coastal Southwest France, although they are not part of typical French colonial collections of the seventeenth century or later. Most of the cooking vessels from Hare Harbor come from Structure 1 and the underwater deposits.

Among the tin-glazed earthenware, several objects are comparable to Spanish productions in form and/or decorative style. They can therefore be considered majolica, and some are also similar to material found on the Red Bay and Middle Bay Basque whaling stations in the eastern Gulf of St. Lawrence. Of particular interest are two porringers with lobed lug handles, one of which is almost complete with only part of one handle missing (Fig. 6.6c) of a form identical to those found on other Basque sites (Niellon 1986:32; Myles 2007: II:122-124). The complete vessel has a polychrome geometric design identical to a design motif known from an Aragonese majolica production center in Muel, Spain, just south of the Spanish Basque provinces and dated to the late sixteenth and very early seventeenth centuries. This porringer was found on top of one of the underwater ballast piles close to the site. The second porringer, found in a test pit on the land site, carries a monochrome 
blue floral design that has also been identified among the Aragonese majolica production of Muel (Fig. 6.6d; Escribano Ruiz, personal communication; Iñanez, personal communication; Alvaro Zamora 2002:209).
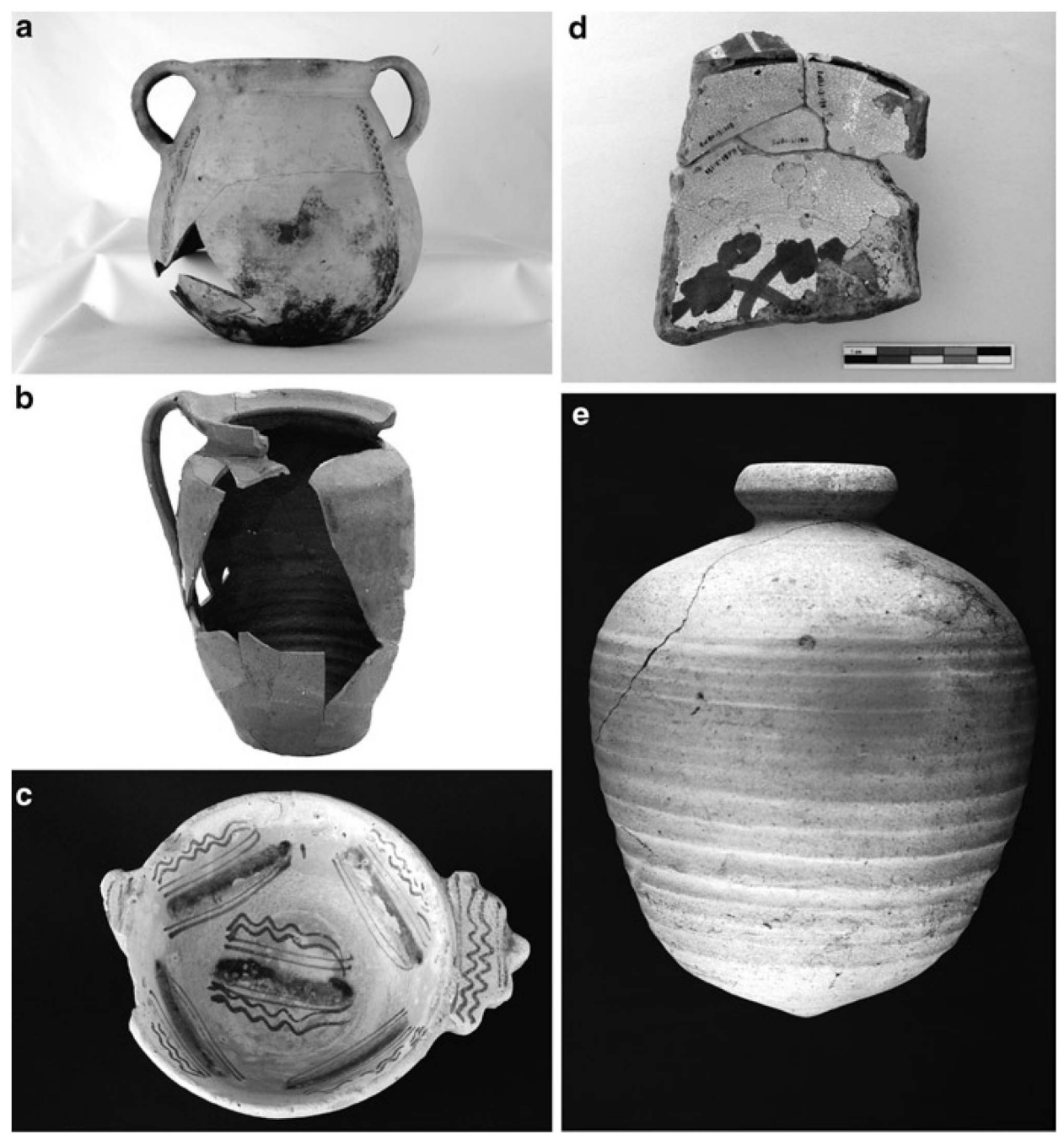

Figure 6.6. Selected ceramic vessels from Hare Harbor-1 excavations. (a) French cooking vessel with applied decoration, mid-sixteenth to mid-seventeenth century, found in underwater Test Pit B-1, associated with a similar vessel, rope fragments, codfish and whale bones, and food remains (photo by Herzog 2009). (b) Normandy Stoneware Salted Food Storage Jar from the Domfront Region (sixteenth to early twentieth century) found partially crushed in situ in Structure 1. Recovered from late seventeenth to early eighteenth century context associated with French glass bottles, various trade beads, Dutch clay pipe fragments, knife fragments, whetstones, and a large variety of other artifacts of unknown date, including possibly intrusive pottery and fine glassware from the early Basque sixteenthcentury occupation (photo by Marc Gadreau, 2003). (c) Spanish Majolica Porringer with bi-chrome geometrical decoration applied with double-brush technique (Muel, Aragon, 
ca. 1530-1610) found underwater on the surface of the large ballast rock pile SP1/SP2 (photo by A. Herzog 2009). (d) Spanish Majolica Porringer with monochrome blue floral decoration (Muel, Aragon, ca. 1530-1610) found in Test Pit 4 (2002) on the steep slope leading from the shore to Area 1, associated with fragments of a small majolica jug, a fragment of an Orange Micaceous Ware pocillo, sherds belonging to a large coarse earthenware cooking vessel, and various other coarse earthenware types (photo by A. Herzog 2009). (e) Iberian Olive Jar, Middle Style (1570-1800), found on surface of the underwater sediments west of ballast SP-1 in 2008 (photo by A. Herzog 2009).

Excavation of Structure 2 yielded other important majolica objects. Two sherds of a vessel of unknown form are luster decorated. Lusterware or refléjo metálico is a type of majolica produced in medieval Spain and popular as a prestige ceramic style up into the sixteenth century, after which production declined rapidly. It received its name from the particularly lustrous decoration achieved by applying overglaze decoration using a pigment containing silver or copper oxides to the vessel's surface after initial decoration and firing. Lusterware was still produced in the seventeenth century and later but by that time had lost much of its prestige value (Lister and Lister 1987:47-48, 87-88).

A few deteriorated majolica sherds that had been exposed to fire, found during excavations of Structure 2, probably belong to a carinated bowl of a form derived from medieval times and regularly found on early Spanish colonial sites. Its decoration is also of typical hispano-mauresque type, and this bowl may thus be linked with the early occupation of the Hare Harbor site.

The stoneware vessels found on the site are mostly Normandy Stoneware storage jars from the Domfront region in Normandy and most come from Structure 1 (Fig. 6.6b). Others were found in 2009 in association with the Inuit houses (Structures 4 and 5). Normandy Stoneware has been found on other Basque whaling sites, but in small quantities (Niellon 1986:28-29; Gusset 2007:II:100-103). This type is more frequently associated with Norman cod-fishing or early French colonial sites (Chréstien and Dufournier 1995:260, 264-267; Décarie 1999:107-111). At Hare Harbor, it seems to date to the later seventeenth- to early eighteenth-century occupation. Only one sherd of Brown Rhenish Stoneware was found, probably coming from a Bartmann bottle found in the Structure 2 area.

Among the varied coarse earthenware collection, two other types could be identified as of Spanish origin: two sherds are attributed to Spanish olive jars, probably of the Middle Style and thus dated between ca. 1570 and 1800 (a more complete olive jar was also found in an underwater deposit during the 2008 excavations, Fig. 6.6e), and one sherd of a type called Orange Micaceous Ware, probably of a drinking vessel such as a pocillo, thus also linking the Hare Harbor site with Spanish Basque occupation. Several other types might be attributed to a Spanish origin, but the identification is as yet unclear. Among them, the second most frequent earthenware type found at Hare Harbor, represented by sherds of cream-white paste partially covered by a yellow-brown glaze, may actually be of Basque origin, as this type closely resembles a ceramic type manufactured at Bilbao during the sixteenth and seventeenth centuries. This type is currently being studied by Basque archaeologists, but further analysis is necessary to confirm identification (Escribano Ruiz, personal communication; Loewen, personal communication). Others may be of French provenance, 
such as three types that have been shown to have certain affinities with storage jars produced in Brittany and found on Newfoundland fishing locations used by Breton fisherman during the sixteenth to eighteenth centuries (Pope, personal communication; Pope and Batt 2008). Did Breton cod-fishing vessels also visit Petit Mécatina Island on Quebec's LNS? Or did Basque fishermen take food supplies in Brittany when picking up salt for the cod-fishing season? Could some of the unidentified types come from other French regions, such as Normandy? Yet another type, represented by three fragments of a green-glazed arcaded chafing dish, is most probably from the Saintonge region in southwestern France and associated with the sixteenth- to early seventeenth-century occupation at Hare Harbor (Hurst 1974:235, 247).

The analysis of the Hare Harbor ceramic collection has thus far proven to be a complex enterprise. Evidence of a late seventeenth- to early eighteenth-century date as established by the presence of Dutch clay pipes, French glass bottles, and glass trade beads is challenged by the presence of ceramic types found in the same archaeological deposits that are identical to those of other Basque whaling stations occupied a century earlier, and by certain types and vessel forms usually encountered in sixteenth- and early seventeenth-century contexts. They also seem to point to various regions of origin in France and Spain. These finds raise questions as to whether Hare Harbor was used by different groups of fishermen over time, a situation that is not unusual at New World sites, many of which were subject to fierce competition among European fishermen.

The distribution of the collection on the site also points to vocational differences. On the one hand, Structure 1 has so far yielded cookware as well as fragments of tableware, and this seems to indicate that food preparation and also consumption were of predominant importance during the early occupation of the area, a function that may well have prevailed during the second period, during which we find the Normandy stoneware storage jars in this area. Work in the Structure 2-3 area, on the other hand, has yielded only a few ceramic objects, which generally are related to the earlier Basque occupation and thus are considered intrusive. The absence of ceramics related to food consumption contemporary with the Structure 2 occupation may thus confirm the identification of this building as a workshop (smithy, cooperage), with clear indications for some tasks related to the whaling and fishing industry, such as repair of metal objects and cask assembly. The particular character of some of the earlier vessels, such as Lustreware, may actually hint at the presence of individuals of a higher social status during the early Basque-related occupation of the site. However, further analyses, using quantitative methods in conjunction with other elements of the material culture, are necessary to refine the picture of Hare Harbor's history.

\section{Fish Remains}

The fish remains from Hare Harbor-1 were analyzed at the Brooklyn College Zooarchaeology Laboratory of the City University of New York. All bone elements were identified and recorded using the NABONE Zooarchaeological Database Recording System (McGovern 2007). Selected elements were measured for size reconstructions. The archaeofauna almost in its entirety was composed of fish belonging to the cod family (Table 6.2) with only 
one other bone present. Within the cod family, the majority of the elements belonged to the North Atlantic cod. Because fish bones were not distributed throughout the underwater stratigraphic profile and were found concentrated in one level, near the top of the profile, it is almost certain that they accumulated during the ca. 1700 occupation rather than the late sixteenth-century occupation.

\begin{tabular}{llcr}
\hline \multicolumn{2}{l}{ Table 6.2. Identified fish remains from Hare Harbor-1 } & & \\
\hline Scientific name & English common name & NISP count & \% NISP \\
\hline Gadus morhua & Atlantic cod & 1,120 & 78.32 \\
Pollachius pollachius & Pollack & 25 & 1.75 \\
Melanogramus aeglfinus & Haddock & 2 & 0.14 \\
Gadidae, sp. Indet. & Gadid family & 282 & 19.72 \\
Rajidae sp. & Ray family & 1 & 0.07 \\
Total & & 1,430 & 100 \\
\hline
\end{tabular}

Cod for centuries has been a fish of great importance, fueling chiefly economies and connecting distant ports of trade (Perdikaris 1996, 1998, 1999, 2003; Perdikaris et al. 2003; Perdikaris and McGovern 2008a, b). Dried cod, a product that saw its early beginnings in Northern Norway before spreading westward, was quickly identified as a key commercial product. It gave rise to a good part of the medieval Hansa economic infrastructure and was later incorporated into the Basque seafaring tradition.

The Hare Harbor fish bone material was examined for indicators of commercial production and processing to determine whether cod was a processed product suitable for market or whether it was for local consumption. Archaeological signatures for identifying commercial processing have been identified in previous publications (Perdikaris 1996, 1999), and the Hare Harbor-1 material was examined according to these protocols. While the sample size is modest, the numbers are enough to view the results generated from this data with confidence. The bones from Hare Harbor- 1 were compared with a contemporary site from Iceland, Tjarnargata $3 c$, where a significant archaeofauna assemblage shows large amounts of fish processed for the commercial market (Perdikaris et al. 2002; Perdikaris 2003).

In looking at the overall skeletal element distribution, it is instantly apparent that Hare Harbor-1 is represented by cranial elements and very few postcranial or vertebral bones (Fig. 6.7). This pattern compares very well with the Tjarnargata assemblage. Figure 6.8 depicts the element distribution, comparing cranial and postcranial elements. 


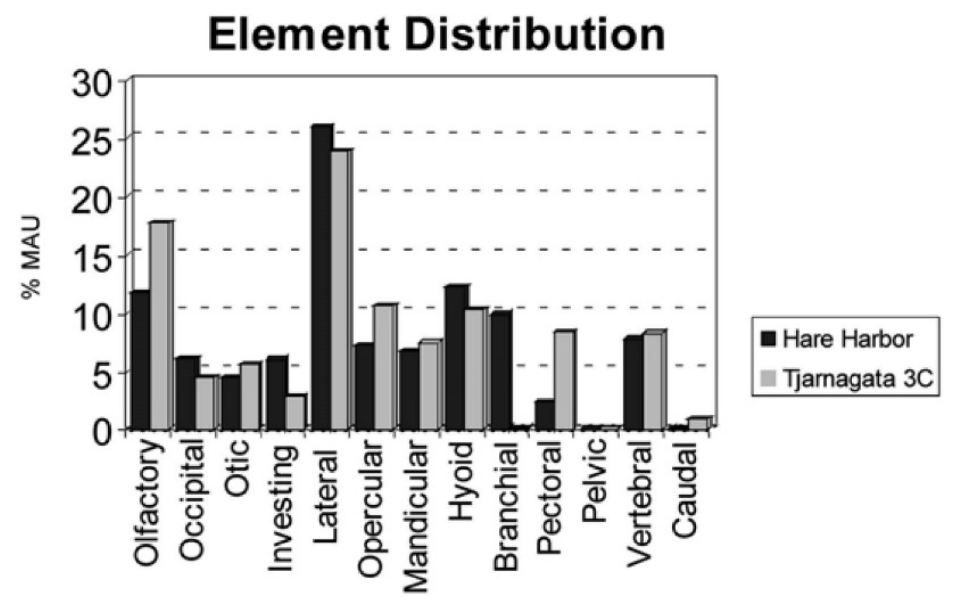

Figure 6.7. Faunal element distribution comparison between Hare Harbor-1 and Tjarnagata-3C (figure by S. Perdikaris, 2009).

\section{Cranial and Vertebral Elements}

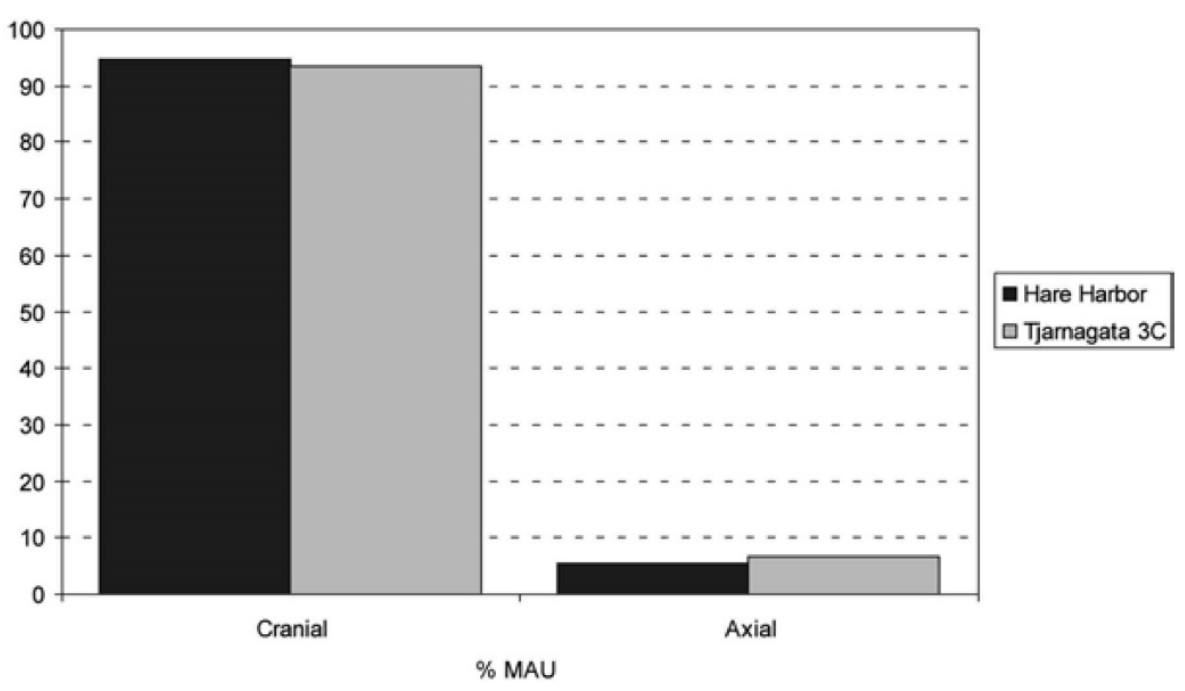

Figure 6.8. Comparison between cranial and vertebral (postcranial) elements of Gadus morhua (figure by S. Perdikaris, 2009).

Both figures indicate a strong differential patterning. In the commercial trade, the body of the fish was the commercial product, whereas the head and proximal thoracic vertebra became the byproduct of this processing (Perdikaris 1996, 1998, 1999; Perdikaris and McGovern 2008a, b). The amount of thoracic and precaudal vertebra present changes according to whether the fish were beheaded and dried in the round without the addition of salt, or were beheaded and split open, a method that can be used for fish that were dried either with or without salt. 
In the split-open fish varieties, the head along with the thoracic vertebra and a few of the precaudal vertebra form the processing byproduct. The material from Tjarnargata $3 \mathrm{C}$ represents primarily fish that was dried in the round. As indicated in Fig. 6.9, the cod at Hare Harbor 1 points to a fish that was split open. The splitopen (bacalao) style product was a trademark of the Basque codfish trade, and the Hare Harbor-1 material well supports this interpretation. In looking at the size graphs (Figs. 6.10 and 6.11), we see that the Hare Harbor-1 fish were smaller than Tjarnargata fish, while their element recovery pattern is consistent with the split-open variety (Perdikaris et al. 2002; Perdikaris 2003).

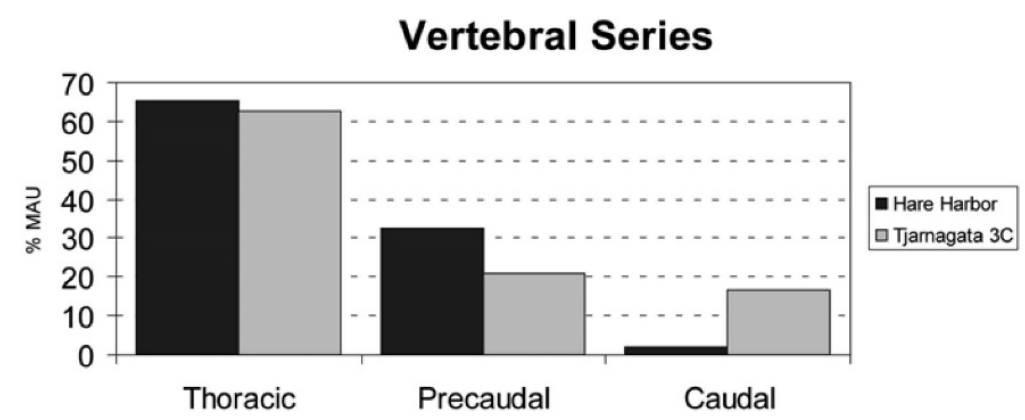

Figure 6.9. Vertebral series comparison between Hare Harbor-1 and Tjarnagata-3C (figure by S. Perdikaris, 2009).

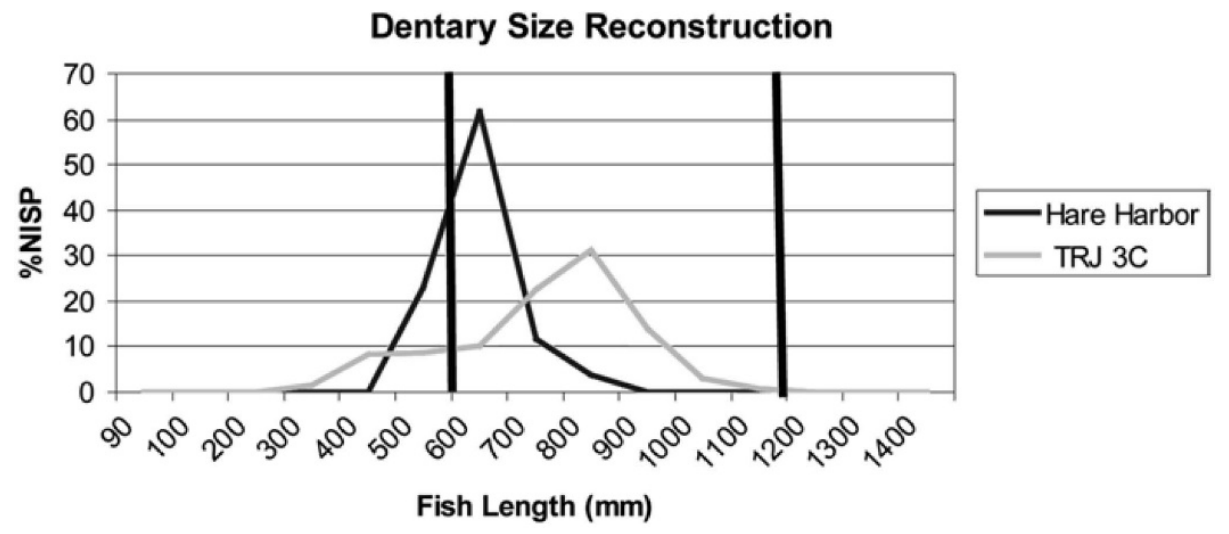

Figure 6.10. Gadus morhua dentary size reconstruction (figure by S. Perdikaris, 2009). 


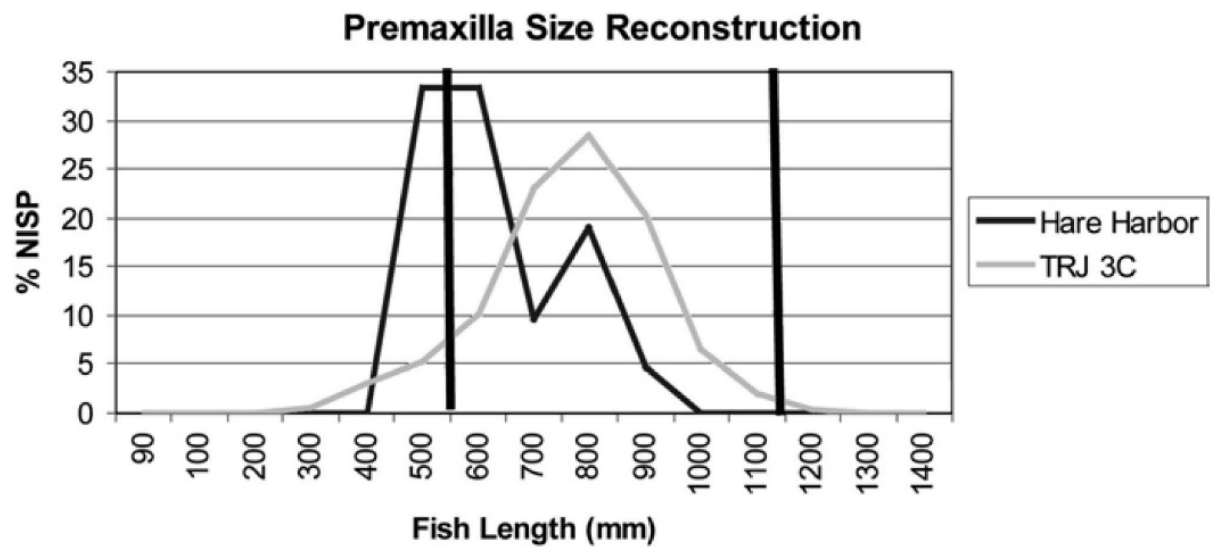

Figure 6.11. Gadus morhua premaxilla size reconstructions (figure by S. Perdikaris, 2009).

It is also interesting to note that in this collection there were only 10 urohyal bones (the bone found in the tongue of the cod) for an approximate minimum of 42 individuals. This difference could indicate possible cod tongue extraction prior to discarding the heads, a practice that would not be unusual since the cod tongue remains a delicacy in many codproducing regions today.

\section{Whale and Mammalian Remains}

At the time of analysis of the mammalian remains in 2006-2008, it seemed that there was only one Basque occupation at Hare Harbor 1 and all bones were studied as a single unit. Identifiable bones did not survive in the acid soils of the surface site, and most other bones came from the fish bone horizon of the underwater site. Small amounts of waterfowl and seal bones are present in this collection, and in 2007 a cow bone was recovered. The nearabsence of harp seal bones suggests the Petit Mécatina Basque crews probably returned to Europe before the late fall harp seal migration. Whale bones were found exposed on the surface of the bottom as well as in excavations. It is likely that all whale bones sampled can be attributed to this context, which most likely belongs to the late sixteenth century component and not ca. 1700. This supposition seems reasonable since by 1700 most of the large whales had been extirpated from the Gulf region, and fishing had become the dominant economy.

The 2007 excavation in underwater Test Pit Z-1 (Fig. 6.12) revealed the articulated bones of the pectoral fin that had been severed from the body of a large whale during the butchery process and dropped to the bottom. Several whale phalanges exposed elsewhere on the bottom had been sawn through their longitudinal axis, apparently as part of the processing procedure. Most of the whale bones were restricted to the east side of the underwater site, where the cove was deepest adjacent to a shore-side cliff. This distribution indicates that whales were towed into the harbor and were butchered beside the shore cliff, where their fins were cut off and discarded, dropping to the bottom in deep water where they would not foul the anchorage. After the blubber was removed, the remaining carcass 
consisting of articulated ribs, vertebrae, and skull bones were, as at Red Bay, towed and dumped in the shallows at the inner end of the harbor, where we observed numerous whale bones embedded in the sea-floor.

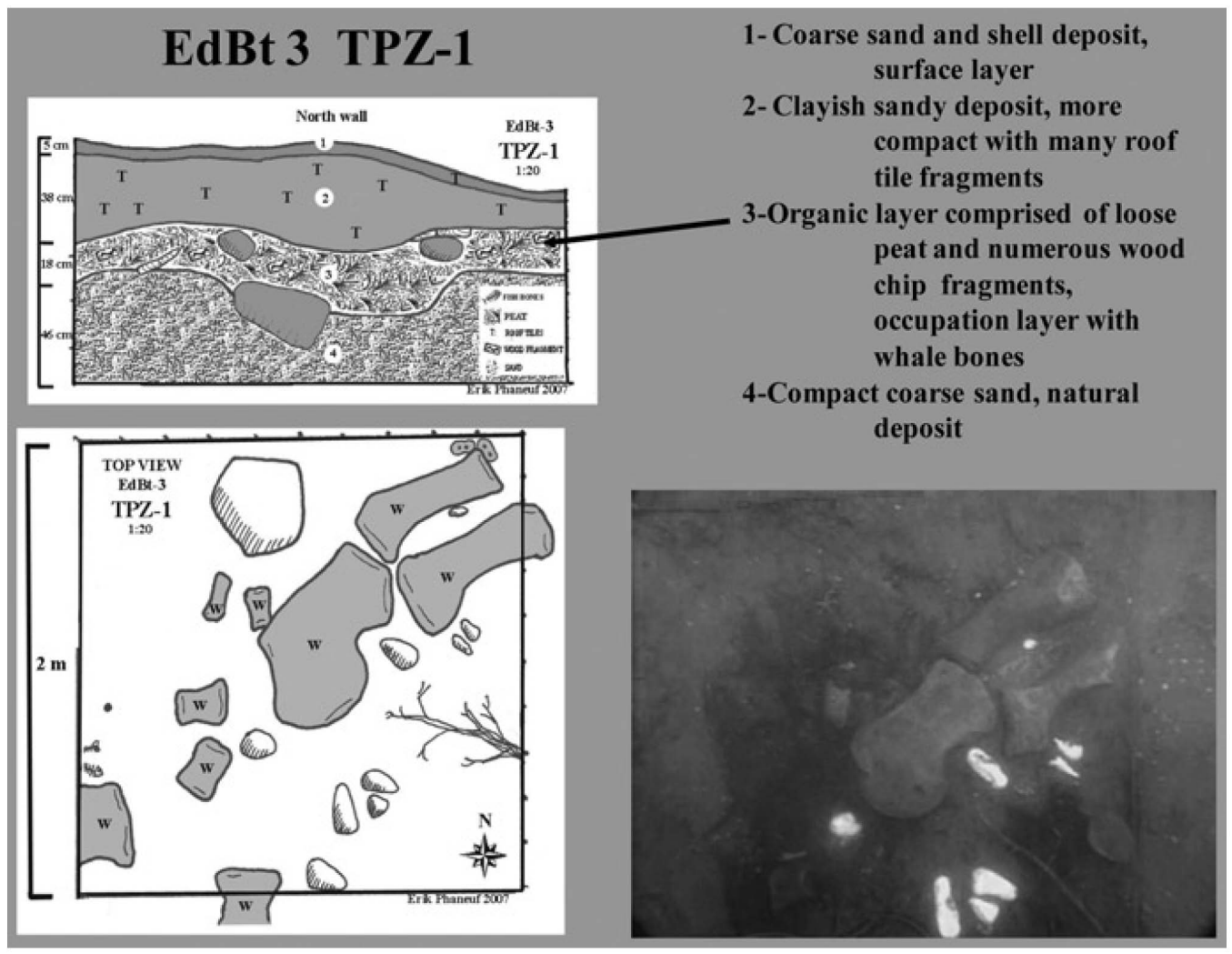

Figure 6.12. Articulated bones and map of a bowhead whale (Balaena mysticetus) pectoral fin excavated from Hare Harbor-1 underwater site, unit TPZ-1, in 2007 (figure by E. Phaneuf and F. Simard, 2008).

Of a larger sample of baleen and whale bone analyzed from the land excavations, only three produced identifiable DNA whereas underwater samples generally had well-preserved DNA. Mitochondrial DNA analysis of the whale bone samples $(n=37)$ revealed that 36 of the bones were from bowhead whales (Balaena mysticetus), and a single specimen was from a humpback whale (Megaptera novaeangliae) (Table 6.3). The mitochondrial haplotypes identified $(n=8)$ have been found previously in bone remains at Basque whaling sites along the coast of Quebec and Labrador (McLeod et al. 2008). DNA analyses also indicated that these samples came from at least seven different individuals. Since mitochondrial DNA analysis provides a very conservative estimate of the number of individuals, there could be several more within the sample set, and it is possible that Mécatina Basques were whaling on a regular basis. Absence of shore-based try-works indicates that rendering took place aboard ship, not on land as in most sixteenth-century sites. 
Fitzhugh ET AL., "SHiP TO SHORE” (2011)

Table 6.3. Results of mitochondrial cytochrome $b$ analysis of bone specimens from Petit Mécatina ${ }^{a}$

\begin{tabular}{|c|c|c|c|}
\hline Lab ID & Field ID & Species & Cytochrome $b$ haplotype \\
\hline WHB0552 & Area $1 \mathrm{~N} / 1 \mathrm{E}$ & Balaena mysticetus & BMYCB3 \\
\hline WHB0553 & Area1 2E/1N & Balaena mysticetus & BMYCB3 \\
\hline WHB0554 & Area $2 \mathrm{E} / 0 \mathrm{~N}$ & Balaena mysticetus & BMYCB3 \\
\hline WHB0555 & Petit Mécatina underwater deposit & Megaptera novaeangliae & MNOCB1 \\
\hline WHB0745 & EdBt-3:1157 & Balaena mysticetus & BMYCB10 \\
\hline WHB0747 & EdBt-3:1159 & Balaena mysticetus & ВMYСВ07 \\
\hline WHB0751 & EdBt-3:1457 & Balaena mysticetus & BMYCB07 \\
\hline WHB0753 & EdBt-3:1459 & Balaena mysticetus & BMYCB13 \\
\hline WHB0754 & EdBt-3:1453 & Balaena mysticetus & BMYCB07 \\
\hline WHB0756 & EdBt-3:1434 & Balaena mysticetus & BMYCB13 \\
\hline WHB0757 & EdBt-3:1435 & Balaena mysticetus & BMYCB07 \\
\hline WHB0759 & EdBt-3:1437 & Balaena mysticetus & BMYCB13 \\
\hline WHB0760 & EdBt-3:1438 & Balaena mysticetus & ВMYCB07 \\
\hline WHB0761 & EdBt-3:1439 & Balaena mysticetus & ВMYCB08 \\
\hline WHB0762 & EdBt-3:1440 & Balaena mysticetus & ВMYCB07 \\
\hline WHB0763 & EdBt-3:1441 & Balaena mysticetus & ВМYСВ07 \\
\hline WHB0764 & EdBt-3:1442 & Balaena mysticetus & BMYCB07 \\
\hline WHB0765 & EdBt-3:1443 & Balaena mysticetus & BMYCВ08 \\
\hline WHB0766 & EdBt-3:1449 & Balaena mysticetus & ВMYСВ07 \\
\hline WHB0767 & EdBt-3:1450 & Balaena mysticetus & BMYCB08 \\
\hline WHB0768 & EdBt-3:1475 & Balaena mysticetus & BMYCB07 \\
\hline WHB0771 & EdBt-3:1445 & Balaena mysticetus & ВMYСВ07 \\
\hline WHB0772 & EdBt-3:1446 & Balaena mysticetus & Incomplete sequence \\
\hline WHB0774 & EdBt-3:1448 & Balaena mysticetus & ВМYСВ08 \\
\hline WHB0775 & EdBt-3:1451 & Balaena mysticetus & BMYCB13 \\
\hline
\end{tabular}

${ }^{a}$ Lab ID denotes the NRDPFC laboratory ID; Field ID denotes the Smithsonian excavation units or specimen catalog numbers. The first three samples come from the land deposits and the remainder from underwater contexts.

Until relatively recently, sixteenth/seventeenth-century Basque whaling activities in the western North Atlantic have been thought responsible for substantially reducing the population size of the North Atlantic right whale (Eubalaena glacialis), an endangered species with about 300-350 individuals remaining (IWC 2001; Kraus et al. 2001, 2005). The identification of primarily bowhead whale specimens at this site corroborates previous research (Rastogi et al. 2004; McLeod et al. 2008) that Basques targeted the bowhead whale and not the right whale in the Strait of Belle Isle and Gulf region. The presence of the bowhead whale, an Arctic species with a distribution ranging from about $60^{\circ}-85^{\circ} \mathrm{N}$, this far into the Gulf of St. Lawrence during the occupation of this site (about 1690-1730) highlights questions that still remain regarding both the historical distribution of the species and historical climate characteristics during this time period (see McLeod et al. 2008). 


\section{Site History}

As noted above, stratified peat layers in the bog between Structure 1 and Structure 2/3 reveal a sequence of at least 8-10 reoccupations of the site. The underwater stratigraphy provides a different kind of history, beginning with wood chips and debitage, indicating the initial occupation involved construction of site facilities such as workshops, piers, ship repair, or possibly small boats. This was followed by a period of whaling, and finally by market-oriented codfish production. Throughout the occupation, ballast piles accumulated and multiplied and ceramic vessels were lost or discarded overboard along with shoes, leather garments, glass, rope, and large numbers of clay tiles broken in outbound voyages from Europe. The formation of 11 separate ballast piles suggests that multiple vessels used the anchorage cove, moored perpendicular to the shore (a common practice in southern European and Mediterranean harbors that helped maximize the number of ship berths), with a line ashore and an anchor to seaward. The larger central piles indicate the preferred mooring locations in the center of the site's small cove; but on occasion, several vessels must have been present simultaneously, requiring them to take less desirable berths in peripheral locations. We have considered but rejected the possibility that the stone piles are foundations for shore-fast pier pilings based on the steep inclination of the bottom, and depths up to $12 \mathrm{~m}$, absence of pole stubs in the stone piles, the piles being too close together to accommodate vessels between piers, and lack of shore access due to steep cliffs at the shore end of the western piles.

\section{Basques and the Inuit in Grand Bay: Changing Geographic and Social Landscapes}

Samuel Robertson (1843:28), in a paper read in 1841 to the Literary and Historical Society of Quebec, considered the possibility of Inuit and Basque occupations along the Quebec LNS:

"... there is no want of remains of buildings and tumuli [stone Inuit graves] of such ancient date [pre-Columbian], that tradition ascribes them to the Esquimeaux, which in one instance, at least, was false: this occurred three years ago, where a person had occasion to remove part of a 'Terasse', to make a garden. He found an iron instrument, of about eighteen inches in length, of a crooked form, which I conjectured to be a Cerp, such as were used [as vine-pruning tool?] 300 years ago in Spain -if my supposition is right, the remains must have been those of the Basques, as the Norman and Breton countries are not vine countries."

This statement is prescient, for today Hare Harbor is known locally to the nearby French community of Tête à la Baleine as "Eskimo Harbor." While the precise location of the LNS terrace garden Robertson is referring to is not known, the Hare Harbor site confirms his intuition of both Inuit and Basque occupations on this LNS coast. What Robertson speculated might be a grape-pruning implement may more likely have been a whale butchering knife. Robertson's report also indicates that LNS residents in the early 1800s were aware 
of the Basque and Inuit history of their region, even though today all but the barest traces of this oral history have been lost.

Other historical notes are less specific but convey graphic detail that may relate directly to Hare Harbor. In a 1729 report describing events of 1728, Martel de Brouague (1923:384) notes conflicts in the Strait of Belle Island and along the Quebec coast between various European groups and Native Inuit and Indians. In one instance, Brouague remarks on an Inuit family murdered "at Mécatina" by a party of "French and Indians" in which all were killed except a woman and young boy, who were sent to Quebec.

The presence of Inuit and European artifacts dated to ca. 1700 at the Hare Harbor cookhouse, adjacent to Inuit winter dwellings whose floor deposits include both European and Inuit artifacts of a similar time period, and in one case Inuit toys, supports both the supposition of contemporaneity between these structures and the likelihood that the Europeans - whether Basque or others - working at Hare Harbor employed Inuit families as camp assistants, hunters, and winter site custodians. The congruence of Brouague's location and oral history of "Eskimo Harbor" lends further credence to the supposition that Hare Harbor may have been the site of the Mécatina incident of 1728 .

It is generally accepted that sixteenth-century Inuit movements into southern Labrador and the Straits were undertaken as raids to acquire European materials. These forays mostly took place in spring before Basque vessels began returning from Europe (Martijn 1974, 1980; Martijn and Clermont 1980; Taylor 1980; Stopp 2002). During the early 1600s, after the decline of Basque voyaging, the Straits became at least a sporadic extension of the central Labrador Inuit settlement area (Fitzhugh 2009). Two multifamily Inuit winter house villages have been found in the Brador region, one probably dating to the eighteenth century (Dumais and Poirier 1994) and the other, found during our Gateways Project surveys, probably dates to the sixteenth century (Fitzhugh 2009). The presence of these settlements marks the beginning of a new phase of Inuit-European relationships in the Straits. By 1700, goals such as service employment, collaboration, and social reciprocity seem to have become attractive to Inuit as a safer way to engage the growing numbers and groups of Europeans operating in the Newfoundland-Gulf region.

At the same time, this southward expansion opened up new settlement and subsistence resources and expanded opportunities for trade and obtaining European goods for these Inuit pioneers. However the geography of cultural relations between European agents and different Native players made such engagements in the country west of the Straits dangerous. Conflicts in the Gulf between European groups, between these groups and Native groups, and between European-Native alliance groups were frequent and unpredictable. These conditions would also have resulted in serious problems for Inuit as well as for their European patrons. Although not well studied, such conflicts in the seventeenth to nineteenth centuries are noted by Cleophas Belvin (2006), who indicates that political jurisdiction of the LNS shifted back and forth between the French and English, officially and unofficially, resulting in periods of anarchy that attracted even American privateers. Evidence of such activities may be reflected in the multiple burning and destruction episodes seen at Hare Harbor.

One of the interesting issues raised by the diversity and widespread sources of Mécatina finds, as indicated especially in the ceramic analyses, is the question of "Basque" 
attribution for the site's European components. How do we identify the regional, ethnic, or political affiliation of an archaeological site of this type, with materials from many different European sources, given the multinational and increasingly "globalized" nature of European commerce in late seventeenth-century North Atlantic venturing? The 2009 excavations provided clear evidence of a distinct sixteenth-century Basque horizon lying on sterile beach sands beginning at the eastern edge of the S-1 pavement. This $5-10 \mathrm{~cm}$ thick, greasy, charcoal-filled level contained numerous small cooking hearths whose bases were paved with broken, eroded, and charred earthenware sherds, and one hearth was surrounded by large strips of baleen. These finds are unquestionably Basque, but their soil level contained relatively few tile fragments. Overlying this layer were $30-40 \mathrm{~cm}$ of highly fragmented tiles with few ceramic finds, relatively few nails, no stoneware, and a single large iron axe. On top of, between, and below the S-1 pavement, the assemblage was entirely different, containing only a few pieces of earthenware but much Normandy stoneware, glass beads, nails, and other materials commonly found in eighteenth-century sites of a more northern, non-Iberian origin. Perhaps, this assemblage is not Basque but north Biscayan, Breton, Norman, or Jerseyian. But given considerable amounts of tile present in the above-floor pavement perhaps the voyages that produced these remains originated and were financed in the Spanish or French Basque region (accounting for the use of tiles and some earthenwares) but included other materials representing wider economic relations to the north.

The stratigraphic evidence for whaling, followed by a focus on commercial cod fishing, conforms to the general development of fisheries in the Newfoundland-Gulf region. However, significant whaling activity seems to have ended in Gulf and Newfoundland waters after 1600, when the Dutch began pursuing whales along Labrador and further north. Both land and underwater deposits of the sixteenth-century Basque component contain strong evidence of whaling, while the seventeenth/eighteenth-century component and the Inuit houses with stoneware, clay pipes, and beads are associated with commercial cod fishing. It is possible that tiles and earthenware found on the S-1 cookhouse floor may have resulted from mixing and site disturbance when the S-1 floor was constructed, but this does not explain the quantity of "fresh" tiles found in the cultural layer on top of the pavement. Given the sites' many repeated occupations, which included refurbishing of existing structures, it may be difficult to resolve the questions surrounding the identification of these later occupations without direct historical documentation. But for the moment, continuing land and underwater archaeology at Hare Harbor is providing information about the provisioning, economics, organization, and intercultural relations of Basque and other early occupations of the "forgotten Labrador" portion of the Western North Atlantic.

\section{Conclusion}

The evidence reported here contributes archaeological information supporting sixteenthcentury Basque and later European occupations of the "Grand Bay" region and provides settlement evidence for at least short-term year-round Inuit expansion into the Gulf during what was, from the Inuit perspective, the "favorable" (cooler) climate of the Little Ice Age. Hare Harbor also shows that Europeans (perhaps of Basque origin) and Inuit were 
engaged - at least for a period around 1700-in a joint economic enterprise beneficial to both parties. Details of this collaboration remain to be discovered from ongoing excavations of Inuit winter houses that appear to have been integral to the functioning of the later cod-fishing period of this site. The diverse features of the archaeological record now unfolding at Hare Harbor may be seen as a microcosm of the larger field of environmental, social, and economic interactions that engaged diverse European and Native groups in an important "gateway" region of the New World. Once central to European interests, this region later became peripheral and geographically remote from westward-shifting European colonial endeavors and is still poorly known historically and archaeologically today. As indicated by this chapter, viewing its European and Native history through a landscape approach that combines maritime and underwater archaeology provides a fuller picture of the interplay of land and history by incorporating multiple lines of evidence, local and regional perspectives, and integration of land and maritime domains. The early history of this region is particularly well-suited to such an approach because much of its material record is preserved underwater in a cold-water environment and is relatively accessible in shallow harbors and bays. Because Basques lived and worked aboard their ships, their underwater middens, wrecks, and sunken chalupas contain a trove of archaeological data that, as shown at Red Bay and Hare Harbor, can be studied in association with their adjacent land sites to provide a fuller, more integrated, and wider landscape of early North American and European history.

Acknowledgments - The collection of the data presented in this chapter has been facilitated by many institutions and individuals. We thank the Smithsonian's Endowment Program, Robert Bateman Fund, and donations from General and Mrs. Raymond Mason and Anina Glaize. Smithsonian field crews too numerous to name helped acquire the field data. Pitsiulak skipper Perry Colbourne; our Colbourne and Vatcher-Evans life-support systems in Lushes Bight and Harrington Harbor; our divers Erik Phaneuf and Frederic Simard, Marilyu Girard-Rheault, Ben Ford, and Vincent Delmas; Brad Loewen of University of Montreal who provided field support and assistance in historical archaeology; artifact cataloguers Anja Herzog and Frederic Simard; Government of Quebec Conservation Laboratory; Laurie Penland and the Smithsonian Dive Program; and Marcia Bakry, Hanul Kim, and Lauren Marr for illustration assistance. As usual, the authors alone are responsible for results reported here.

\section{References}

Alvaro Zamora, María Isabel 2002 Cerámica aragonesa. 3 vols. Departamento de Obra Social y Cultural, Zaragoza, Ibercaja.

Auger, Réginald, William Fitzgerald, and Laurier Turgeon 1992 Île aux Basques 1991: fouilles archéologiques et reconnaissances. Report on file, Ministère de la Culture et de la Communication, Québec, QC.

Azkarate, A., J. A. Hernádez, and J. Núez 1992 Balleneros vascos del siglo XVI. Estudio arqueológico y contexto histórico (Chateau Bay, Labrador, Canada). Servicio Central de Publicación del Gobierno vasco, Victoria-Gasteiz, ES. 
FitZHUGH ET AL., "ShiP TO SHORE” (2011)

Bakker, Peter 1989 "The Language of the Coast Tribes Is Half Basque": A Basque-American Indian Pidgin in Use between Europeans and Native Americans in North America, ca. 1540-ca. 1640. Anthropological Linguistics 31(3/4):117-147.

Barkham, Selma (Huxley) 1980 Notes on the Strait of Belle Isle During the Period of Basque Contact with Indians and Inuit. Études/Inuit/Studies 4(1-2):51-58.

Barkham, Selma (Huxley) 1984 The Basque Whaling Establishments in Labrador 1536-1632-A Summary. Arctic 37(4):515-519.

Barkham, Michael 1994 French Basque 'New Found Land' Entrepreneurs and the Import of Codfish and Whale Oil to Northern Spain, c. 1580 to c. 1620: the Case of Adam de Chibau, Burgess of Saint-Jean-de-Luz and 'Sieur de St. Julien.' Newfoundland Studies 10(1):1-43.

Belvin, Cleophas 2006 The Forgotten Labrador: Kegashka to Blanc Sablon. A Short History of the Lower North Shore. McGill-Queens University Press, Montréal, QC.

Brouague, Marcel de 1923 Divers Mémoires de M. de Brouague au Conseil de Marine, Rapport de l'Archiviste de la Proncince de Québec pour 1922-23, pp. 356-406, Ls. A. Proulx, Québe, QCc.

Chréstien Jean-Pierre, and Daniel Dufournier 1995 Les grès béarnais au Canada, in: L'aventure maritime, du golfe de Gascogne à Terre-Neuve, Actes du 118e congrès national annuel des sociétés historiques et scientifiques, Pau, octobre 1993. Éditions du comité des travaux historiques et scientifiques, pp. 251-270, Paris.

Décarie, Louise 1999 Le grès français de Place-Royale. Les Publications du Québec, 2nd edition, Québec, QC.

Douglas, William A., and J. Bilbao 2005 Amerikanuak. Basques in the New World. Center for Basque Studies. University of Nevada Press, Reno, NV.

Drouin, Pierre 1988 Des Baleiniers Basques á l’Ile Nue de Mingan. Canadian Journal of Archaeology 12:1-15.

Dumais, Pierre, and J. Poirier 1994 Témoinage d'un Site Archéologiques Inuit, Baie des Belles Amours, Basse-Côte-Nord. Recherches Amérindiennes au Québec 23(1-2):18-30.

Edvardsson, R., and M. Rafnsson 2006 Basque Whaling around Iceland: Archaeological Investigation in Strákatangi, Steingrímsfjörđur. Bolungarvik (Iceland): The Natural History Institute of Vestjirđir. <http://www.galdrasyning.is/baskarnir.pdf>

Fitzhugh, William W. 2006 Cultures, Borders, and Basques: Archaeological Surveys on Quebec's Lower North Shore. In From the Arctic to Avalon: Papers in Honour of James A. Tuck. Lisa Rankin and Peter Ramsden, editors, pp. 53-70. British Archaeological Reports International Series 1507.

Fitzhugh, William W. 2009 Exploring Cultural Boundaries: the 'Invisible' Inuit of Southern Labrador and Quebec. In On the Track of the Thule Culture from Bering Strait to East Greenland, Bjarne Grønnow, editor, pp. 129-148. Studies in Archaeology and History, 15. National Museum of Denmark, Copenhagen, DK.

Fitzhugh, William W., and others (editors) 2001-2010 St. Lawrence Gateways Project Field Reports published annually by Arctic Studies Center, National Museum of Natural History, Smithsonian Institution. Copies on file at Government of Quebec, Ministry of Culture and Communication. $<$ http://www.mnh.si.edu/arctic/html/pub_field.html>

Fitzhugh, William W., and others (editors) 2006-2010 St. Lawrence Gateways Project Annual Reports published in The Provincial Archaeology Office Newsletter. Provincial Archaeology Office, Government of Newfoundland and Labrador. Department of Tourism, Culture, and Recreation. St. John's, Newfoundland. <http://www.tcr.gov.nl.ca/tcr/pao/Newsletters/Newsletters.htm>

Fitzhugh, William W., Anja Herzog, Sophia Perdikaris, and Brenna McLeod 2008 Baleines, Morues, et les Basques: l'Archéologie d'un Site Basque du XVIIe siècle dans le Golfe du St. Laurent, 
Québec. Paper presented at Les actes du 133e congrès du Comité des travaux historiques et scientifiques, Québec, QC.

Grenier, Robert 1988 Basque Whalers in the New World: the Red Bay Wrecks. In Ships and Shipwrecks of the Americas, George Bass, editor, pp. 69-84. Thames and Hudson, London, UK.

Grenier, Robert, Marc-André Bernier, and Willis Stevens (editors) 2007 The Underwater Archaeology of Red Bay: Basque Shipbuilding and Whaling in the 16th century. 5 volumes. Parks Canada, Ottawa, ON.

Gupta, Anika 2009 The Basques Were Here. Smithsonian Magazine 39(11):27-30.

Gusset, Gérard 2007 La poterie commune et le grès des sites subaquatique et terrestre à Red Bay. In L'archéologie subaquatique de Red Bay: La construction navale et la pêche de la baleine basques au XVIe siècle. Robert Grenier, Marc-André Bernier and Willis Stevens, editors, pp. II:51-120. Parcs Canada, Ottawa, ON.

Herzog, Anja, and Jean-François Moreau 2004 Petit Mécatina 3: a Basque Whaling Station of the Early 17th Century? The Gateways Project 2004: Surveys and Excavations from Chevery to Jacques Cartier Bay, William W. Fitzhugh, Yves Chrétien, and Helena Sharp, editors, pp. 76-87. Arctic Studies Center, Smithsonian Institution. <www.mnh.si.edu/arctic/html/pdf/report\%20gateways\%2005_ copy.pdf $>$

Herzog, Anja, and Jean-François Moreau 2006 European Glass Trade Beads, Neutron Activation Analysis, and the Historical Implications of Dating Seasonal Basque Whaling Stations in the New World. In 34th International Symposium on Archaeometry, 3-7 May 2004, Zaragoza, Spain, pp. 495502. Zaragoza, Institución “Fernando el Católico," Publication 2,621. <http://ifc.dpz.es/publicaciones/ver/id/2610>

Herzog, Anja 2008 L'île du Petit Mécatina sur la Basse-Côte-Nord du Québec: Résultats Préliminaires des Analyses Céramiques d'un Site Voué aux Activités de Pêche Saisonnière dans le Golfe du Saint-Laurent entre le XVIe et le XVIIIe Siècle. Paper presented at the 133e Congrès du Comité des Travaux Historiques et Scientifiques, Québec, QC.

Herzog, Anja 2009 Petit Mécatina Island: Basque and French Whalers and Cod-Fishers in the Gulf of St. Lawrence from the 16th to the 18th Centuries. Paper presented at the Annual Meeting of the Council for Northeast Historical Archaeology, Québec, QC.

Herzog, Anja 2010 The Study of Petit Mecatina 3 and the History of Whaling and Cod-Fishing in the Gulf of St. Lawrence During the 16th to the early 18th Century. Paper presented at the 2010 Conference on Historical and Underwater Archaeology, Amelia Island, FL.

Hurst, J. G. 1974 Sixteenth- and Seventeenth-Century Imported Pottery from the Saintonge. In Medieval Pottery from Excavations: Studies Presented to Gerald Clough Dunning, with a Bibliography of his Works, Vera I. Evison, H. Hodges and J. G. Hurst, editors, pp. 221-255. John Baker, London, UK.

Huxley, Selma (Barkham) 1987 Los Vascos y las Pescerías Transatlánticas (1517-1713) [Basque Fisheries in the North Atlantic (1517-1713)]. In Itsasoa : El Mar de Euskalerria : La Naturaleza, el Hombre y su Historia, vol. 3: Los Vascos en el Marco Atlántico Norte. Siglos XVI y XVII [The Basques in the North Atlantic in the 16th and 17th Centuries]. E. Ayerbe and S. Huxley, editors, pp. 26-210. Eusko Kultur Eragintza ETOR, Donostia-San Sebastián.

IWC (International Whaling Commission) 2001 Report on the Workshop on the Comprehensive Assessment of Right Whales: A Worldwide Comparison. Journal of Cetacean Research and Management, Special Issue 2:1-60.

Kraus, S. D., P. K. Hamilton, R. D. Kenney, A. R. Knowlton, and C. K. Slay 2001 Reproductive Parameters of the North Atlantic Right Whale. Journal of Cetacean Research and Management, Special Issue 2:231-236. 
Fitzhugh ET AL., "SHiP TO SHORE” (2011)

Kraus, S. D., M. W. Brown, H. Caswell, C. W. Clark, M. Fujiwara, P. K. Hamilton, R. D. Kenney, A. R. Knowlton, S. Landry, C. A. Mayo, W. A. McLellan, M. J. Moore, D. P. Nowochek, D. A. Pabst, A. J. Read, and R. M. Rolland 2005 North Atlantic Right Whales in Crisis. Science 309:561562.

Lalande, D. 1989 Archaeological Excavations at Bon-Désir: Basque Presence in the St. Lawrence Estuary. Northeast Historical Archaeology 18:10-28.

Lister, Florence C., and Robert H. Lister 1987 Andalusian Ceramics in Spain and New Spain: A Cultural Register from the Third Century B.C. to 1700. The University of Arizona Press, Tucson, AZ.

Loewen, Brad 2009 Historical Data on the Impact of 16th-Century Basque Whaling on Right and Bowhead Whales in the Western North Atlantic. Canadian Zooarchaeology 26:3-24.

McGovern, Thomas H. 2007 NABONE 8th Edition Computer Software Package. <www.nabohome.org> McLeod, Brenna, M. W. Brown, M. J. Moore, W. Stevens, Selma H. Barkham, Michael Barkham, and B. N. White 2008 Bowhead Whales, and Not Right Whales, Were the Primary Target of 16th-17th Century Basque Whalers in the Western North Atlantic. Arctic 61(1): 61-75.

Malakoff, David 2007 Uncovering Basques in Canada. American Archaeology 11(2):12-17.

Marc Gadreau 2003 Laboratoire de Reserve d'archaeologie, MCCCFQ.

Martijn, Charles A. 1974 Archaeological Research on the Lower Saint-Lawrence North-Shore, Québec. In Archaeological Salvage Projects 1972, W. J. Byrne, editor, Mercury Series Paper 15, pp. 112130. Archaeological Survey of Canada, Ottawa, ON.

Martijn, Charles A. 1980 La Présence Inuit sur la Côte-Nord du Golfe St.-Laurent à l'Époque Historique, Études/Inuit/Studies 4(1-2):105-125.

Martijn, Charles A., and Norman Clermont (editors) 1980 Les Inuit du Québec-Labrador Meridional/ The Inuit of Southern Quebec-Labrador. Études/Inuit/Studies 4(1-2).

Morandière, Charles, de la 1962-1966 Histoire de la Pêche Française à la Morue en Amérique Septentrionale (des origines à 1789). 3 vols. Maisonneuve et Larose, Paris.

Myles, Virginia 2007 Majolique Espagnole des Sites Subaquatique et Terrestre. In L'Archéologie Subaquatique de Red Bay: La Construction Navale et la Pêche de la Baleine Basques au XVIe Siècle, Robert Grenier, Marc-André Bernier, and Willis Stevens, editors, pp. II:120-130. Parks Canada, Ottawa, ON.

Niellon, Françoise 1986 Intervention Archéologique sue les Sites Historiques de la Baie des Cinq Lieues et de la Baie de Milieu, Basse-Côte-Nord. Report on file, Ministère de la Culture et de la Communications, Québec, QC.

Niellon, Françoise, and G. Jones 1984 Reconnaissance sur les Sites Historiques de la Basse Côte-Nord, été 1983. Rapport d'activités. 3 vols. Report on file, Ministère de la Culture et de la Communications, Québec, QC.

Niellon, Françoise, and A. McGain 1987 La Station Baleinière Basque de la Baie du Milieu: Recherche Archéologique 1987 sur le Site EiBi-10. Quebec, Municipalité de la Côte-Nord du Golfe Saint-Laurent. Report on file, Ministère de la Culture et de la Communications, Québec, QC.

Perdikaris, Sophia 1996 Scaly Heads and Tales: Detecting Commercialization in Early Fisheries. Archaeofauna. Ichthyoarchaeology and the Archaeological Record. In Proceedings of the 8th Meeting of the ICAZ Fish Remains Working Group 5, A. Morales, editor, pp. 21-33. ICAZ, Madrid, ES.

Perdikaris, Sophia 1998 The Transition to a Commercial Economy: Lofoten Fishing in the Middle Ages: a Preliminary Report. Proceedings of the Seventh ICAZ Conference, September 1994, Konstanz, Germany. Anthropozoologica 25-26:505-510. 
Fitzhugh ET AL., "SHiP TO SHORE” (2011)

Perdikaris, Sophia 1999 From Chiefly Provisioning to Commercial Fishery: Long Term Economic Change in Arctic Norway. World Archaeology 30(3):388-402.

Perdikaris, Sophia 2003 Freshwater and Marine Fish in Inland Sites in North Iceland. In Presencia de la Arqueoictiologia en Mexico: Libro de Memorias de la 12a Reunion del Grup de Trabajo en Restos de Peces de Internations Council for Archaeozoology, A. F. Guzman, O. J. Polaco, and F. J. Aguilar, editors, pp. 135-138. Grup de Trabajo en Restos de Peces de Internations Council for Archaeozoology, Mexico City, MX.

Perdikaris, Sophia, C. Amundsen, and Thomas H. McGovern 2002 Report of Animal Bones from Tjarnargata 3C, Reykjavík, Iceland. NORSEC Zooarchaeology Laboratory Reports, vol. 1. City University of New York, New York, NY.

Perdikaris, Sophia, Thomas H. McGovern, Y. Krivogorskaya, and M. Waxman 2003 Early Modern Fisher-Farmers at Finnbogastadir and Gjogur in Northwest Iceland. Presencia de la Arqueoictiologia en Mexico: Libro de Memorias de la 12a Reunion del Grup de Trabajo en Restos de Peces de Internations Council for Archaeozoology. A. F. Guzman, O. J. Polaco, F. J. Aguilar, editors, pp. 139-145. Grup de Trabajo en Restos de Peces de Internations Council for Archaeozoology, Mexico City, MX.

Perdikaris, Sophia, and Thomas H. McGovern 2008a Viking Age Economics and the Origins of Commercial Cod Fisheries in the North Atlantic. In Consequences of the North Atlantic Fisheries in the Middle Ages and Early Modern Period. Interdisciplinary Approaches in History, Archaeology, and Biology, L. Sicking, editor, pp. 61-91. Brill Publishers, Boston, MA.

Perdikaris, Sophia, and Thomas H. McGovern 2008b Codfish and Kings, Seals and Subsistence: Norse Marine Resource Use in the North Atlantic. In Human Impacts on Ancient Marine Ecosystems: a Global Perspective, T. C. Rick and J. M. Erlandson, editors, pp. 187-215. University of California Press, Berkeley, CA.

Phaneuf, Erik 2008 Hare Harbor-1 Underwater Site 2007 Preliminary Report. In The Gateways Project 2007: Land and Underwater Excavations at Hare Harbor, Mecatina, William W. Fitzhugh and Erik Phaneuf, editors, produced by Abigail McDermott and Lindsey Fell, pp. 83-99. Arctic Studies Center, Smithsonian Institution, Washington. D.C. <http://www.mnh.si.edu/arctic/html/pdf/ Gateways2007FINALsmall.pdf>

Pope, Peter E. 2004 Fish into Wine: The Newfoundland Plantation in the Seventeenth Century. University of North Carolina Press, Chapel Hill, NC.

Pope, Peter E., and Michael Batt, with contributions by Michael J. Hughes and Roger T. Taylor 2008 Post-medieval Breton Earthenwares in Newfoundland. Post-Medieval Archaeology 42(1):48-74.

Proulx, J.-P. 1993 Les Basques et la Pêche de la Baleine au Labrador au XVIe siecle. Études en Archéologie, Architecture, et Histoire. Lieux Historiques Nationaux, Service de Parcs, Environment Canada, Ottawa, ON.

Proulx, J.-P. 2007 Basque Whaling in Labrador: an Historical Overview. In The Underwater Archaeology of Red Bay: Basque Shipbuilding and Whaling in the 16th Century, Robert Grenier, Marc-André Bernier and Willis Stevens, editors, pp. I:25-96. Parks Canada, Ottawa, ON.

Rastogi T., M. W. Brown, B. A. Brown, T. R. McLeod, T. R. Frasier, R. Grenier, S. Cumbaa, J. Navarajah, and B. M. White 2004 Genetic Analysis of 16th C. Whalebone Prompts a Revision of the Impact of Basque Whaling on Right and Bowhead Whales in the Western North Atlantic. Canadian Journal of Zoology 82:1647-1654.

Robertson, S. 1843 Notes on the Coast of Labrador. Transactions of the Literary and Historical Society of Québec 4(1):27-53.

Stevens, Willis, and Stephen L. Cumbaa 2007 Marine Archaeology and Zooarchaeology of the 16thCentury Whaling Harbour of Red Bay. In The Underwater Archaeology of Red Bay: Basque 
Shipbuilding and Whaling in the 16th Century, Robert Grenier, Marc-André Bernier, and Willis Stevens, editors, pp. I:189-200. Parks Canada, Ottawa, ON.

Stopp, Marianne 2002 Reconsidering Inuit Presence in Southern Labrador. Études/Inuit/Studies 26(2):71-106.

Taylor, J. Garth 1980 The Inuit of Southern Quebec-Labrador: Reviewing the Evidence. Etudes/ Inuit/Studies 4(1-2):185-194.

Trudel, François 1978 L'impact des Pêcheries Sédentaires Françaises sur les Inuit dans la Région du Détroit de Belle-Isle. Un Survol Historique. Actes de la Première Conférence sur les Inuit, Octobre 1978. Université Laval, Québec, QC.

Trudel, François 1980 Les Relations Entre les Français et les Inuit au Labrador Méridional, 1660-1760. Études/Inuit/Studies 4(1-2):135-146.

Tuck, James A. 1982 A Sixteenth Century Whaling Station at Red Bay, Labrador. In Early European Settlement and Exploitation in Atlantic Canada, G. M. Story, editor, pp. 41-52. Memorial University of Newfoundland, St. John's, NF.

Tuck, James A. 1983-86 Excavations at Red Bay, Labrador. In Archaeology in Newfoundland and Labrador 1982-1986, Jane Sproull Thomson and Callum Thomson, editors, Annual Reports no. 3:95117, 4:70-81, 5:224-247, and 6:150-158. Historical Resources Division, Government of Newfoundland and Labrador, St John's, NF.

Tuck, James A., and Robert Grenier 1989 Red Bay, Labrador: World Whaling Capital, A.D. 1550-1600. Atlantic Archaeology, Ltd. Newfoundland, St. John's, NF.

Turgeon Laurier 1994 Vers une Chronologie des Occupations Basques du Saint-Laurent du XVIeXVIIe Siècle: un Retour à l'Histoire. Recherches Amérindiennes au Québec 24(3):3-15.

Turgeon, Laurier 1995 Pêcheurs Basques du Labourd en Atlantique Nord (XVIe-XVIIIe siècle): Ports, Routes et Trafics. Itsas Memoria. Revista de Estudios Maritimos del Pais Vasco 3:163-178.

Westerdahl, Christer (ed.) 2010 A Circumpolar Reappraisal: the Legacy of Gutorm Gjessing. Proceedings of a Conference. Norwegian University of Science and Technology. Christer Westerdahl, editor. British Archaeological Reports. 